\title{
Sensitivity and Tolerance of Different Annual Crops to Different Levels of Banana Shade and Dry Season Weather
}

\section{OPEN ACCESS}

Edited by:

Paulo Mazzafera

Campinas State University, Brazil

Reviewed by:

Italo Herbert Lucena Cavalcante, Federal University of São Francisco

Valley, Brazil

Manosh Kumar Biswas, University of Leicester, United Kingdom

*Correspondence: Guy Blomme

g.blomme@cgiar.org

Specialty section:

This article was submitted to Crop Biology and Sustainability, a section of the journal

Frontiers in Sustainable Food Systems

Received: 26 March 2020 Accepted: 20 October 2020 Published: 25 November 2020

Citation:

Blomme G, Ntamwira J, Kearsley E,

Bahati L, Amini D, Safari $N$ and

Ocimati W (2020) Sensitivity and Tolerance of Different Annual Crops to Different Levels of Banana Shade and Dry Season Weather.

Front. Sustain. Food Syst. 4:545926. doi: 10.3389/fsufs. 2020.545926

\begin{abstract}
Guy Blomme ${ }^{1 *}$, Jules Ntamwira ${ }^{2}$, Elizabeth Kearsley ${ }^{3}$, Liliane Bahati ${ }^{4}$, Daniel Amini ${ }^{4}$, Nancy Safari ${ }^{4}$ and Walter Ocimati ${ }^{5}$

${ }^{1}$ Bioversity International, ILRI, Addis Ababa, Ethiopia, ${ }^{2}$ INERA-Mulungu Research Station, Bukavu, Democratic Republic of the Congo, ${ }^{3}$ Independent Consultant, Kearsley Consulting, Antwerp, Belgium, ${ }^{4}$ Bioversity International, CIAT, Bukavu, Democratic Republic of the Congo, ${ }^{5}$ Bioversity International, Kampala, Uganda
\end{abstract}

Intercropping in small-holder production systems in East and Central Africa is very common and offers potential for significant yield and environmental benefits. However, the reduced light availability under banana canopies constrains the success of the intercrop in banana systems. Determining a balance between the optimal spacing/densities of banana plants with optimized intercrop selection based on their sensitivity and tolerance to shade is imperative. This study, through extensive field experiments performed in South Kivu, DR Congo investigated the resilience of a wide range of food and forage crops to varying banana shade levels. The same crop species grown as monocrops served as controls. Quantitative yield assessments showed yam, sweet potato, ginger and forage grasses to have a good potential to grow under moderately dense to dense banana fields. Taro, soybean, mucuna, chili, eggplant, and Crotalaria sp. performed well in sparsely spaced banana fields with moderate shading. Cassava and soybean showed limited tolerance to shade. Intercropping in banana systems is also generally confined to the rainy seasons due to the high sensitivity of most annual intercrops to long dry weather in the dry season months. We also thus assessed the sensitivity of chickpea and mucuna to the long dry weather of the dry seasons and found them to have great potential for extending farming production into the dry season. Overall, we show that careful selection and allocation of crops with varying sensitivity to various banana shade levels and dry season weather can potentially increase whole field productivity.

Keywords: banana, biomass, cover crop, Democratic Republic of Congo, intensification, mucuna

\section{INTRODUCTION}

Banana (Musa sp.) producing landscapes in the East and Central African region are characterized by small ( $<2 \mathrm{ha}$ ) and highly fragmented farms (van Asten et al., 2004; Niroula and Thapa, 2005; UBOS, 2010; Wairegi et al., 2010; Tinzaara et al., 2018). Fragmentation of farms is hastened by the high population densities and land tenure system. Population densities of up to 470 people $/ \mathrm{km}^{2}$ have been reported in parts of the region (The World Bank Group, 2016). The land tenure system involves parents dividing their land between children, resulting over generations into smaller 
fragmented land sizes thus making it hard to consolidate land for agricultural production. The smallness and continuous fragmentation of farms hastens land degradation and limits the financial returns farmers can obtain from their land (Niroula and Thapa, 2005; UBOS, 2010). To use the available land optimally, farmers therefore often diversify crop types within fields through intercropping to augment yield without the additional need for more farmland (Ocimati et al., 2013, 2019; Tittonell and Giller, 2013; Ntamwira et al., 2014). Intercropping can provide potential co-benefits which can help maintain or even increase the sustainability of the farming systems. Firstly, soil degradation being a major issue in banana production systems (Wairegi et al., 2010; van Asten et al., 2011) can be mitigated through the intercrop. The increased soil coverage by plant canopy and an overall increased root network in the field improves conservation of soil moisture through reduced soil water evaporation and reduces the risk of erosion by stabilizing the soil surface layers (Lithourgidis et al., 2011). Additionally, intercropping can improve soil fertility of the field specifically when using nitrogen fixing crops (e.g., legumes), as will decomposed residue and mulch from parts of the intercrop not harvested (Lithourgidis et al., 2011; Gebru, 2015). This is particularly important for small-holder farmers in Central and East Africa where the use of fertilizers is minimal (Blomme et al., 2018). A second cobenefit from intercropping is a reduced incidence of pests and diseases often attributed to the improved biodiversity allowing for an increase in populations of natural enemies of the pests (Lithourgidis et al., 2011; Mulumba et al., 2012; Gebru, 2015; Ocimati et al., 2018). Intercropping has also been shown to effectively suppress weeds (Jensen et al., 2005; Gebru, 2015; Ocimati et al., 2019), leaving more resources for the crops that provide actual yield. The minimized effort in weed management and the reduced need for both herbicides and pesticides increase the cost-effectiveness of the intercropping system. Finally, the diversification of crops reduces the risk of total crop failure (Lithourgidis et al., 2011) providing greater financial stability for farmers.

In Central and East Africa, small-holder farms predominantly intercrop banana with short maturing crops in, respectively, open or young banana fields (Ntamwira et al., 2013). Intercropping in newly established banana fields e.g., works well with beans, coffee, maize and sweet potatoes (Ouma, 2009). Intensification of intercropping in more mature banana fields is however highly constrained by the reduced light availability. The lightdemanding nature of most short-stature crop species therefore restricts their intercropping to the most sparsely spaced banana fields. In dense banana fields e.g., in eastern Democratic Republic of Congo (DR Congo), it's also common for farmers to cut banana leaves, at the onset of an annual cropping season, to increase the amount of light reaching the shorter intercrops, a practice that however reduces the economic efficiency of the system (Ocimati et al., 2019). Several more shade-tolerant crops, e.g., tuber crops Colocasia sp. (taro) and Xanthosoma sp. (cocoyam), have been shown to perform well under mature banana plantations (Blomme et al., 2018). Nevertheless, limited information is available on the shade-tolerance or sensitivity of a wider variety of crops for use in higher shade levels of denser banana fields. Given the small land sizes, exploration of species that can thrive under shade offers a good alternative for increasing yield and/or nutritional diversity of these farms.

Additionally, intercropping in banana systems in Central Africa is mostly confined to the rainy seasons with only few plant species [e.g., multipurpose trees, banana and coffee (Coffea spp.) allowing for a year-round production (Blomme et al., 2018)]. Farmers also often leave root and tuber crops [mainly taro, sweet potato (Ipomoea batatas) and cassava (Manihot esculenta) planted during the rainy season on the field during the dry season and harvest them based on household needs (Blomme et al., 2018)]. Most short-stature banana intercrops however cannot thrive in drier conditions and small-holder farmers cannot irrigate to extend their production to the dry seasons. Integration of crop species that are less sensitive to long dry weather (i.e., less sensitive to heat stress) conditions and can thrive when soil moisture content is low would enable farmers to extend their production into drier months thus offering an opportunity for higher total biomass yields. Soil coverage during the dry season would also be specifically advantageous for reducing the pressures of heat stress and moisture loss on the field (Blomme et al., 2018). Integration of crop species that are less sensitive to long periods of dry weather would thus allow for a more optimal use of available land as additional yield could be obtained.

This study therefore assessed the tolerance or sensitivity of a wide range of food and forage crop species to varying shade levels of open to dense banana fields. We assessed the performance of the known shade-tolerant crops taro and bird's eye chili (Capsicum annum) and the semi shadetolerant crops cassava, yam (Dioscorea sp.) and ginger (Zingiber officinale) (Johnston and Onwueme, 1998, Sreelathakumary and Rajamony, 2002, Okwuowulu, 2005), and of crops for which less (or contrasting) information on shade-tolerance is available, including mucuna (Mucuna pruriens), chickpea (Cicer arietinum), soybean (Glycine max), sweet potato, and eggplant (Solanum melongena) (reviewed in Blomme et al., 2018). Two crops mucuna and chickpea shown to have a great potential for withstanding drier conditions (Johansen et al., 1994; Berger et al., 2004; Chiu, 2004), were also tested for their performance during the dry season. Finally, the integration of forage species (including grasses and shrubs) as hedges and borders as an additional means to augment land utilization within these banana systems is investigated.

\section{MATERIALS AND METHODS}

\section{Study Area}

This study was conducted through extensive field experiments set-up in the South Kivu province of the DR Congo. The experiments were carried out between March 2015 and July 2019 across 3 locations, namely, the Katana center $\left(02^{\circ} 13.427^{\prime} \mathrm{S}\right.$, $\left.028^{\circ} 49.674^{\prime} \mathrm{E} ; 1,647 \mathrm{masl}\right)$, the INERA-Mulungu research station $\left(02^{\circ} 20.042^{\prime} \mathrm{S}, 028^{\circ} 47.311^{\prime} \mathrm{E} ; 1,707 \mathrm{masl}\right)$ and Kavumu $\left(02^{\circ} 17.4^{\prime}\right.$ S, $028^{\circ} 48.24^{\prime}$ E; $1,744.3$ masl). The three sites are located within the same administrative boundary and within $20 \mathrm{~km}$ from each other. This region receives an annual precipitation of 1,656 \pm $235 \mathrm{~mm}$ (2015-2018) with one long dry season from May till 
September (monthly rainfall $\leq 150 \mathrm{~mm}$ ) (Figure 1 ). The second short dry season (January-February), with an annual monthly rainfall of about $150 \mathrm{~mm}$ separates the two annual cropping seasons (Figure 1). For the first cropping cycle (season A), crops are planted in September and harvested between December and January, while for the second cropping cycle (season B) crops are planted from mid-February to March and harvested in May. Cumulative rainfall is higher in season A compared to season B (Figure 1).

The Katana site has highly fertile non-acidic volcanic granitic clay soils composed of a thick humus layer (Lunze, 1988, 2000). At INERA-Mulungu, soils are volcanic-derived and reasonably fertile (Kempers and Zweers, 1986). The Kavumu site has heavy clay soils with a pronounced A horizon, slightly acidic, with low organic matter, nitrogen and phosphorus levels, and altogether rather poor. Detailed characteristics of the soils at the three sites are provided in Table $\mathbf{1}$.

\section{Experimental Design}

Various crop species (roots and tubers, vegetables, forages, and cover crops) were planted within mature banana fields with different shading intensities. Across the various banana cultivars grown in the test plots, banana canopy size varied according to planting density and banana mat structure. The resulting shade level differences, which influence intercrop growth, were captured as photosynthetically active radiation (PAR) using a photometer as a basis for comparison across treatments. An ACCUPAR photometer probe (Model LP-80, Decagon Devices, Pullman, WA, USA; Decagon Devices, 2004) was used to measure the PAR $\left(\mu \mathrm{mol} / \mathrm{m}^{2} / \mathrm{s}\right)$ received under the leaf canopy for the different banana shade treatments and above the monocrops. At least 4 PAR measurements were taken in each intercropped treatment replicate (giving a total of at least 12 measurements per treatment). Measurements were taken at $50 \mathrm{~cm}$ from a banana plant at a height of $30 \mathrm{~cm}$ above the intercrops and between 11.00 a.m. and 3.00 p.m. In addition, four PAR measurements at a height of $30 \mathrm{~cm}$ above the sole annual crops were also taken at the center of each mono-cropped plot/ replicate. For all experiments across the three sites, a randomized complete block design was used. A total of 16 crop species were evaluated across sites, with only mucuna, taro, Setaria sp., elephant grass (Pennisetum sp.), Calliandra calothyrsus, and Leucaena leucocephala evaluated at multiple sites.

\section{Katana Experiments}

At Katana, two mature banana fields, one comprising of the East African highland beer banana cultivar "Nshika" (AAA-EAH) and the other of a mixture of high yielding banana cultivars were used for the experiments. The mixed cultivar field had cultivars "T6" (plantain), "NSH20" (cooking), "NSH42" (beer) and "FHIA03" (dessert). The "Nshika" field was comprised of three banana plant densities $(2 \times 2 \mathrm{~m}, 2 \times 3 \mathrm{~m}$, and $3 \times 3 \mathrm{~m}$ spacings $)$ while the mixed cultivar field had a spacing of $3 \times 4 \mathrm{~m}$. The $3 \times 3 \mathrm{~m}$ spacing is the most recommended spacing for banana in the study region, while lower spacings of $2 \times 2 \mathrm{~m}$ and $2 \times 3 \mathrm{~m}$ are common for banana mono-cropping and $3 \times 4 \mathrm{~m}$ for banana intercrops. Prior to the establishment of crops to assess for shade-tolerance or sensitivity and/ or sensitivity to long dry weather, these fields had been intercropped with beans and amaranth until canopy shade level no longer allowed for these intercrops to grow. During this period, de-suckering to retain only 3 plants per mat (mother plant and two suckers) was carried out routinely at planting of the annual crops in the "Nshika" plots, while irregular de-suckering was carried out in the mixed banana cultivar plot. The crops assessed for sensitivity to shade or dry weather were established in February 2016 and September 2016 for the "Nshika" and mixed cultivar plot, respectively.

The crop species assessed for their sensitivity to shade were first introduced in February 2016 under the four banana planting densities. The crop species included the tuber crops cassava, a sweet variety named "Sawasawa," taro (Colocasia sp.; a shade-tolerant and prolific variety "Ishikazi") and yam (a provitamin A rich variety "Nyaluliga"), the spice crop "red bird's eye chili' (variety "Lushendo") and the cover crop mucuna (Mucuna pruriens).

The tuber crops and chili were harvested after 12 months while mucuna was harvested after 4 months. Mucuna was grown across the various banana planting densities during the rainy cropping season B (planted in March and harvested in June) and in a separate trial also during the subsequent dry season (planted in May and harvested in August) (cf. Figure 1). The May to August mucuna crop was established to test for both shade and dry weather sensitivity or tolerance. Specifically, for cassava and taro, harvesting of young leaves as a vegetable prior to the final tuber harvest was carried out. To test the impact of this practice on the final tuber yield, young leaf harvesting treatments with intensities of a third or half of all leaves removed were performed. These tests were done across both the intercrops and the monocrops and compared to the yield when no young leaves were harvested.

\section{INERA-Mulungu Experiments}

At INERA-Mulungu, a mature cooking banana field (cultivar: AAA-EAH, "Barhabesha") at two spacing densities of $2 \times$ $2 \mathrm{~m}$ and $4 \times 4 \mathrm{~m}$ and a mature beer banana field (cultivar: AAA-EAH, "Nshika") with a $3 \times 4 \mathrm{~m}$ spacing were available and used. Here the "Barhabesha" $(2 \times 2$ and $4 \times 4 \mathrm{~m})$ banana fields were intercropped in the wet seasons $\mathrm{A}$ and/or $\mathrm{B}$ with chickpeas, ginger, eggplant, the forage crop Crotalaria juncea, four varieties of sweet potatoes and mucuna in subplots (Supplementary Table 2). Ginger and eggplant were harvested after 9 and 12 months, respectively. Crotalaria sp. was planted only during cropping season B and harvested after 4 months. All sweet potato varieties were planted during cropping season B and harvested after 5 months. For the chickpea crop, in addition to shade tolerance (assessed during cropping season A), the sensitivity of chickpea to long dry weather conditions of the dry seasons was assessed over the months of May to August and in the drier months in between the two cropping seasons (December till March) and chickpea yield during these seasons was compared with that from the cropping season A planting. The dry season chickpea was planted $\sim 1$ month to the end of season B (early May) to ensure the crop benefitted from the residual water in the soil. In the third trial, chickpea was planted 


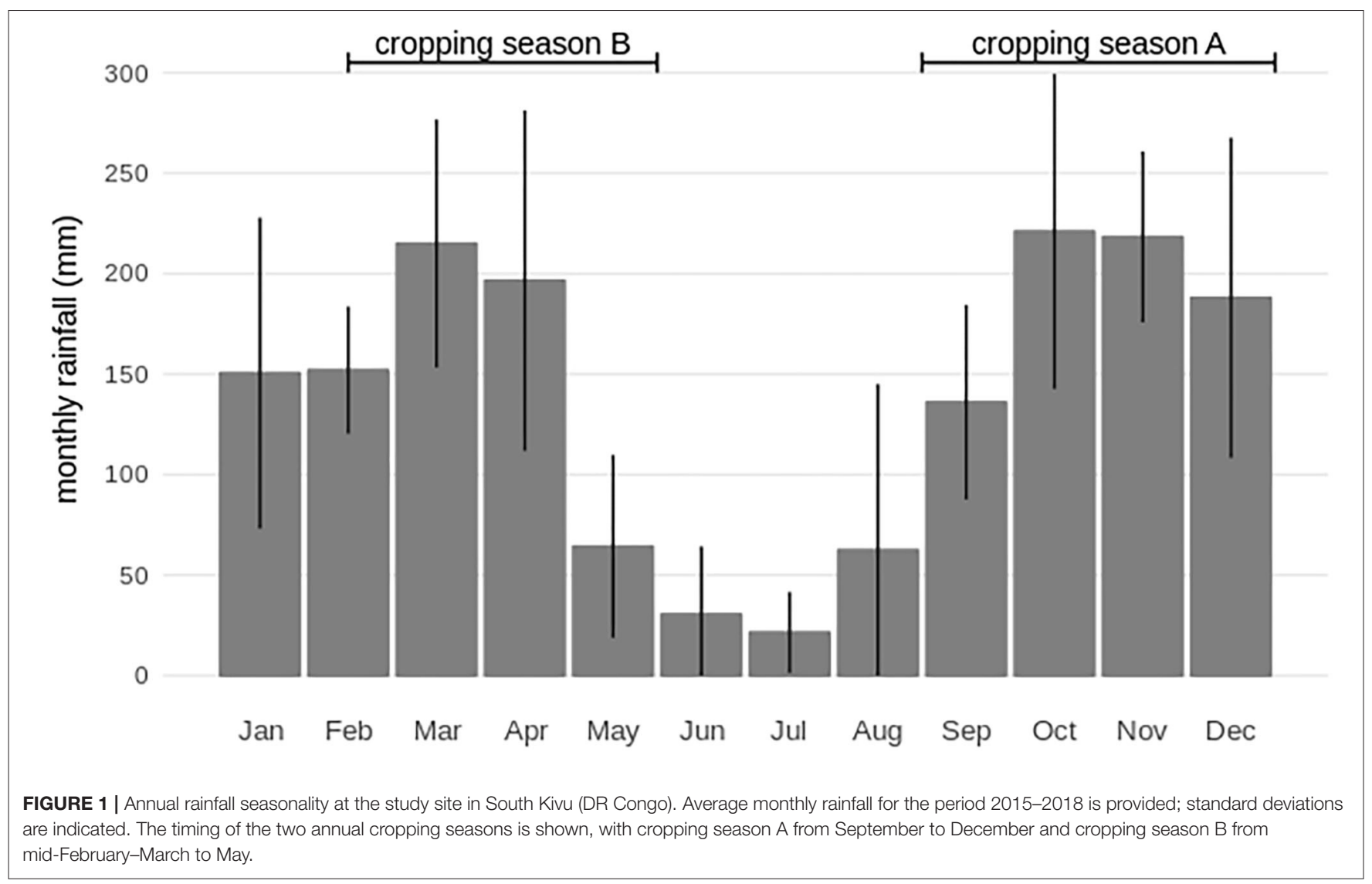

TABLE 1 | Soil characteristics at Katana, Kavumu and INERA-Mulungu.

\begin{tabular}{|c|c|c|c|c|c|c|c|}
\hline Sites & $\mathrm{pH}$ & OM (\%) & N (\%) & $P(p p m)$ & Ca (ppm) & Mg (ppm) & K (ppm) \\
\hline Katana & $6.8 \mathrm{a}( \pm 0.2)$ & $7.2 \mathrm{a}( \pm 0.6)$ & $0.31 \mathrm{a}( \pm 0.03)$ & $100 b( \pm 18)$ & $5569 b( \pm 861)$ & $1480 a( \pm 121)$ & $692 \mathrm{a}( \pm 113)$ \\
\hline Kavumu & $6.1 \mathrm{~b}( \pm 0.2)$ & $5.3 b( \pm 0.3)$ & $0.26 b( \pm 0.06)$ & $46 c( \pm 11)$ & 4230c ( \pm 738$)$ & $928 \mathrm{~b}( \pm 80)$ & $179 c( \pm 47)$ \\
\hline INERA-Mulungu & $6.8 \mathrm{a}( \pm 0.5)$ & $6.8 \mathrm{a}( \pm 0.6)$ & $0.30 \mathrm{a}( \pm 0.02)$ & $112 \mathrm{a}( \pm 10)$ & $6264 a( \pm 852)$ & $1429 a( \pm 213)$ & $371 b( \pm 99)$ \\
\hline LSD & 0.21 & 0.4 & 0.01 & 9.6 & 574.7 & 102.7 & 64.1 \\
\hline Fpr & 0.001 & 0.001 & 0.001 & 0.001 & 0.001 & 0.001 & 0.001 \\
\hline
\end{tabular}

For each site soil pH, organic matter (OM), nitrogen content $(N)$, phosphorus content $(P)$ and calcium (Ca), magnesium (Mg) and potassium (K) are provided. At Katana and Kavumu, averaged values are given of samples collected at the onset of the trials in 2014 and at the end of the trials in 2017. At INERA-Mulungu, soil characteristics were only determined at the

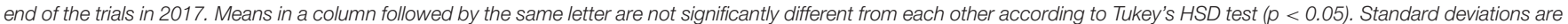
provided between brackets.

in December, i.e., during the last rains before the beginning of the drier period in between the two annual cropping seasons. The chickpea crop grew over a duration of 4 months in all three trails. The mucuna crop established at the beginning of the regular cropping seasons A and B, was allowed to grow into the drier months as cover crops. Thus, crops planted in September (season A) were harvested at the end of February, covering the periods in between the regular cropping seasons, and crops planted in March (cropping season B) were harvested in August, covering the dry period. The performance of mucuna as a cover crop was also assessed in the dry seasons between the two cropping seasons (September to December and March to May) in subplots under banana of different spacings (Supplementary Table 2). Mucuna planted in the dry season were planted 1 month early (May or December) to benefit from the residual soil moisture.

In the "Nshika" $3 \times 4 \mathrm{~m}$ banana field only mucuna was grown. Mucuna was assessed in the drier periods in between the two cropping seasons as described for the $2 \times 4 \mathrm{~m}$ "Barhabesha" fields above. For all crop and fodder species evaluated under different shade intensities, mono-cropped fields with equal replications as for the intercrops were established as controls.

\section{Kavumu Experiment}

At Kavumu a new banana field (beer cultivar; AAA-EAH, "Nshika") was established in March 2015 with a spacing of 3 $\times 4 \mathrm{~m}$. Here, the performance of the tuber crop taro (Colocasia 
esculenta, variety "Astrida"), the legume crop soybean and of the forage grasses Brachiaria ruziziensis and Setaria sphacelata were assessed in intercrop and monocrop situations. The durations from planting (i.e., beginning of the rainy season) to harvest was 4 and 8 months for soybean and taro, respectively. The forage crops, planted at the onset of cropping season $\mathrm{B}$, were first harvested at 6 months and thereafter monthly till the 23rd month of experimentation. The total cumulative biomass across harvests was used for the analysis. Additional trials on mucuna as a cover crop in both intercrop and monocrop formation were also performed, with performance tested through various planting and harvesting periods, including regular cropping seasons extended to the dry season months, year-round cropping and cropping during the dry season months in between the regular cropping seasons. Thus, the duration of the mucuna cropping cycle ranged from 4 to 12 months. At all locations the test crops were planted $30 \mathrm{~cm}$ from the banana mats to minimize damage to banana roots, competition and shading effects.

Forage grasses (elephant grass and Setaria sp.) and shrubs (Calliandra sp. and Leucaena sp.) were planted at all three sites as hedges at the boundary of fields for additional biomass production. These hedge crops were planted during cropping season A. These hedge crops were first harvested after 5 months and thereafter monthly, resulting in a total of 4 harvests. The total cumulative biomass across harvests was used for the analysis. Using forage crops as borders delineating property lines of adjacent farms allows for potential additional yields and optimal use of space. With the exception of taro, ginger, sweet potato for leaves and chili that had been observed to be shade-tolerant, and chickpea that had been reported to be drought-tolerant, the sensitivity of the other crop varieties evaluated to shade or long dry weather conditions was not known at the onset of the trials.

At all three sites above, each crop and treatment combination were replicated thrice while the same crop species grown as monocrops were assessed as controls in subplots separated by $0.5 \mathrm{~m}$. Details on planting material, origin of the intercrops and spacing can be found in Supplementary Table 1, while size of the full subplots, the net plots assessed and/or corresponding number of plants assessed per growth and yield trait and intercrop are provided in the Supplementary Table 2.

Minimal tillage was also performed at planting while hand weeding was used as needed until the soil was covered by the respective test intercrop. In this region, smallholders hardly use inputs such as herbicides for weed control, fertilizers, pesticides for pest control or fungicides on their farms. Where these are used, they are only applied on high value crops. To mimic farmers' behavior, none of these inputs were applied in the various experiments across the three sites.

\section{Data Collection and Analysis}

Data collected in the various experiments/treatments included PAR values, growth and yield attributes. PAR values were measured during the cropping seasons as described in the section on "Experimental design" above. The growth and yield data depended on the crop characteristics and thus varied from one crop species to another. For all experiments and intercrops, fresh and dry biomass yields $(\mathrm{kg})$ were measured at the end of the cropping cycle. According to the interest in yield for each crop, distinctions were made between the yield attributes leaf biomass, total aboveground biomass (stems and leaves), tubers, roots, grain and fruits yields. Specifically, data were collected on tuber yields for the tuber crops; rhizome yield for ginger; fruit yield for eggplants; grain yields for legumes; and vegetative biomass yield for legumes, chili, cover crops, the forage grasses, and the hedges crops. For the grasses and hedges, yields of multiple harvests were added up to obtain the total harvested biomass. For the root and tuber crops, cassava, taro and sweet potato, the weights of harvested leaves were also measured, while plant heights were measured for cassava, taro (at Katana) and the grasses Setaria sp. and Brachiaria sp. To obtain the dry biomass the fresh yields/biomass from the crops were dried in open air for $72 \mathrm{~h}$ and subsequently in an oven at $90^{\circ} \mathrm{C}$ for $48 \mathrm{~h}$.

An analysis of variance using the GenStat v. 11 statistical software (VSN International Ltd, 2009) was conducted to determine the mean yields and effects of the different treatments. The Least Significant Difference (LSD) test at 5\% probability level was used for means separation. Due to the inherent differences between the seasons, mean yields were compared between seasons and treatments. Treatments and crops that appeared across sites were also separately treated due to the inherent differences between the sites.

\section{RESULTS}

\section{Light Reaching Shorter Crops}

Light reaching the crops under the banana canopies varied with banana spacing/ plant densities and banana cultivar types (Table 2). At Katana, light availability to the short intercrops in the beer banana cultivar "Nshika" declined significantly $(p$ $\leq 0.05$ ) with increasing plant density and was also significantly lower than in the open field. PAR declined by 73-89\%, dropping from $1,835 \pm 71 \mu \mathrm{mol} / \mathrm{m}^{2} / \mathrm{s}$ in the open field to $209 \pm 204$ $\mu \mathrm{mol} / \mathrm{m}^{2} / \mathrm{s}$ in the $2 \times 2 \mathrm{~m}$ plots (Table 2 ). The more sparsely spaced $(3 \times 4 \mathrm{~m})$ mixed banana cultivars at Katana that were minimally de-suckered generally had a more robust canopy structure and had little light coming through (PAR of $288 \pm 231$ $\left.\mu \mathrm{mol} / \mathrm{m}^{2} / \mathrm{s}\right)$ compared with the $2 \times 3 \mathrm{~m}\left(475 \pm 321 \mu \mathrm{mol} / \mathrm{m}^{2} / \mathrm{s}\right)$ and the $3 \times 3 \mathrm{~m}\left(501 \pm 268 \mu \mathrm{mol} / \mathrm{m}^{2} / \mathrm{s}\right)$ "Nshika" banana plots (Table 2).

At INERA-Mulungu, although field trials were performed in mature "Barhabesha" plots, relatively high light was recorded under both the open $(4 \times 4 \mathrm{~m})$ and dense $(2 \times 2 \mathrm{~m})$ banana canopies, with respective PAR values of $1,322-1,485 \mu \mathrm{mol} / \mathrm{m}^{2} / \mathrm{s}$ and $603-742 \mu \mathrm{mol} / \mathrm{m}^{2} / \mathrm{s}$ (Table 3). PAR at this site declined by $16 \%-27 \%$ in the $4 \times 4 \mathrm{~m}$ and by $59-66 \%$ in the $2 \times 2 \mathrm{~m}$ fields, respectively. The relatively high light under these fields was most likely due to the regular de-suckering that was practiced in these plots and the less robust structure of "Barhabesha" plants and mats. Here, banana canopy cover did not significantly differ in the period in between the two regular cropping seasons (PAR of $1,116 \pm 299 \mu \mathrm{mol} / \mathrm{m}^{2} / \mathrm{s}$; short dry season from DecemberFebruary), although light availability did reduce during the long 
TABLE 2 | Yield and growth attributes of crops grown at the Katana center: tuber crops taro (variety "Ishikazi"), cassava and yam and spice crop chili.

\begin{tabular}{|c|c|c|c|c|c|c|c|c|c|c|}
\hline \multirow[t]{2}{*}{ Treatments } & \multirow[t]{2}{*}{$\%$ prior leaf harvesting } & \multicolumn{3}{|c|}{ Taro } & \multicolumn{3}{|c|}{ Cassava } & \multirow{2}{*}{$\begin{array}{l}\text { Yams } \\
\text { Tuber yield } \\
\text { (t/ha) }\end{array}$} & \multirow{2}{*}{$\begin{array}{l}\text { Chili } \\
\text { Biomass yield } \\
\text { (t/ha) }\end{array}$} & \multirow[t]{2}{*}{$\operatorname{PAR}\left(\mu \mathrm{mol} / \mathrm{m}^{2} / \mathrm{s}\right)$} \\
\hline & & Leaf yield ( $t / h a)$ & $\begin{array}{l}\text { Tuber yield } \\
\text { (t/ha) }\end{array}$ & Height (cm) & Leaf yield (t/ha) & $\begin{array}{l}\text { Tuber yield } \\
\text { (t/ha) }\end{array}$ & Height (cm) & & & \\
\hline \multicolumn{11}{|c|}{ "Nshika" banana fields* } \\
\hline \multirow{3}{*}{$2 \times 2 m$} & 0 & $0.2 b$ & 1.7 cde $( \pm 0.8)$ & $109 a b c( \pm 62)$ & $0.2 \mathrm{c}$ & Oc $( \pm 0)$ & $159 \mathrm{bc}( \pm 94)$ & $3.74 \mathrm{~b}( \pm 1.39)$ & $0.13 a( \pm 0.09)$ & $209 c( \pm 204)$ \\
\hline & 33 & $0.2 \mathrm{~b}$ & $1.4 \mathrm{e}( \pm 0.5)$ & $89 \mathrm{bc}( \pm 18)$ & $0.1 \mathrm{c}$ & Oc $( \pm 0)$ & 123de $( \pm 35)$ & & & \\
\hline & 50 & $0.4 b$ & 1.7 cde $( \pm 0.8)$ & $83 c( \pm 10)$ & $0.1 c$ & Oc $( \pm 0)$ & 122 de $( \pm 54)$ & & & \\
\hline \multirow[t]{3}{*}{$2 \times 3 m$} & 0 & $0.3 b$ & $3.1 \mathrm{ce}( \pm 0.6)$ & $117 \mathrm{abc}( \pm 9.5)$ & $0.2 \mathrm{c}$ & $0.3 \mathrm{c}( \pm 0.5)$ & $179 \mathrm{bc}( \pm 84)$ & $4.17 \mathrm{~b}( \pm 0.35)$ & $0.15 \mathrm{a}( \pm 0.07)$ & $475 b( \pm 321)$ \\
\hline & 33 & $0.2 \mathrm{~b}$ & 2.4 cde $( \pm 1.4)$ & $93 b c( \pm 14)$ & $0.1 \mathrm{c}$ & Oc $( \pm 0)$ & $102 \mathrm{e}( \pm 47)$ & & & \\
\hline & 50 & $0.4 b$ & 1.6de $( \pm 0.6)$ & $131 \mathrm{abc}( \pm 71)$ & $0.1 c$ & Oc $( \pm 0)$ & $103 e( \pm 49)$ & & & \\
\hline \multirow[t]{3}{*}{$3 \times 3 m$} & 0 & $0.7 \mathrm{~b}$ & $7.6 \mathrm{c}( \pm 1.6)$ & $136 \mathrm{abc}( \pm 36)$ & $0.1 c$ & Oc $( \pm 0)$ & $102 \mathrm{e}$ & $5.66 \mathrm{ab}( \pm 1.36)$ & $0.18 a( \pm 0.01)$ & $501 b( \pm 268)$ \\
\hline & 33 & $0.5 b$ & 5.7 cde $( \pm 1.6)$ & $90 \mathrm{bc}( \pm 37)$ & $0.1 c$ & Oc $( \pm 0)$ & $157 \mathrm{bc}( \pm 38)$ & & & \\
\hline & 50 & $0.6 b$ & 5.1 cde $( \pm 2.9)$ & $114 \mathrm{abc}( \pm 45)$ & $0.2 \mathrm{c}$ & $0.04 \mathrm{c}( \pm 0.1)$ & $151 \mathrm{bcd}( \pm 45)$ & & & \\
\hline \multicolumn{11}{|c|}{ Mixed banana cultivar fields } \\
\hline \multirow[t]{3}{*}{$3 \times 4 \mathrm{~m}$} & 0 & $0.3 b$ & $7.5 \mathrm{~cd}( \pm 1.3)$ & $93 \mathrm{bc}( \pm 14)$ & $0.4 \mathrm{c}$ & $3.2 \mathrm{c}( \pm 2.2)$ & $149 \mathrm{~cd}( \pm 95)$ & $3.45 \mathrm{~b}( \pm 3.61)$ & $0.06 a( \pm 0.03)$ & $288 \mathrm{c}( \pm 231)$ \\
\hline & 33 & $0.4 b$ & $6.5 \mathrm{cde}( \pm 1.4)$ & $92 \mathrm{bc}( \pm 28)$ & $0.3 c$ & $0.6 \mathrm{c}( \pm 0.8)$ & $106 e( \pm 56)$ & & & \\
\hline & 50 & $0.6 b$ & $5.5 \mathrm{cde}( \pm 2.7)$ & $90 \mathrm{bc}( \pm 31)$ & $0.3 \mathrm{c}$ & $0.5 \mathrm{c}( \pm 0.4)$ & $108 \mathrm{e}( \pm 54)$ & & & \\
\hline \multicolumn{11}{|l|}{ Monocrop } \\
\hline & 0 & $1.4 \mathrm{a}$ & $40.2 \mathrm{a}( \pm 9.9)$ & $139 a b( \pm 10)$ & $9.4 a$ & $27.7 \mathrm{a}( \pm 5.0)$ & $245 \mathrm{a}( \pm 58)$ & $9.82 \mathrm{a}( \pm 4.98)$ & $5.22 \mathrm{~b}( \pm 2.03)$ & $1835 \mathrm{a}( \pm 71)$ \\
\hline & 33 & $2.4 a$ & $30.8 \mathrm{~b}( \pm 3.6)$ & $129 a b c( \pm 13)$ & $3.6 b$ & $8 \mathrm{c}( \pm 3)$ & $167 \mathrm{~b}( \pm 35)$ & & & \\
\hline & 50 & $1.9 a$ & $25.2 \mathrm{~b}( \pm 6.4)$ & $160 a( \pm 13)$ & $5.0 \mathrm{~b}$ & $13.1 \mathrm{~b}( \pm 6.5)$ & $183 b( \pm 23)$ & & & \\
\hline LSD & & 1.7 & 5.9 & 53.7 & 3.6 & 3.9 & 31.7 & 4.95 & 1.73 & 105 \\
\hline Fpr & & 0.854 & 0.049 & 0.793 & 0.029 & 0.001 & 0.001 & 0.086 & 0.001 & 0.001 \\
\hline
\end{tabular}

"The mixed cultivar types included: - "T6" (plantain), "NSH2O" (cooking), "NSH42" (beer), and "FHIAO3" (dessert).

Cumulative harvested yield of young leaves, tuber yield and total plant height at harvest are reported for tuber crops. For chill the total aboveground biomass was assessed. Yields are compared between intercrops in banana fields with various spacing $(2 \times 2 \mathrm{~m}, 2 \times 3 \mathrm{~m}, 3 \times 3 \mathrm{~m}, 3 \times 4 \mathrm{~m})$ and monocrops. For taro and cassava, the impact of young leaf harvesting (33\% or $50 \%$ leaf removal) on yield is assessed. Leaf yield represents cumulative harvested leaves during the cropping period. Photosynthetic active radiation (PAR) was measured under the respective banana canopies or in the open field for the monocrops. Means in a column followed by the same letter are not significantly different from each other according to Tukey's HSD test $(p<0.05)$. Standard deviations are provided between brackets. 
TABLE 3 | Yield and growth attributes of crops grown at INERA-Mulungu: chickpeas, eggplant, ginger, and the forage crop Crotalaria sp.

\begin{tabular}{|c|c|c|c|c|c|c|c|}
\hline \multirow[t]{2}{*}{ Planting time } & \multirow{2}{*}{$\begin{array}{c}\text { Treatment (Banana } \\
\text { spacing or monocrop) }\end{array}$} & \multicolumn{2}{|c|}{ Chickpea } & \multirow{2}{*}{$\begin{array}{c}\text { Eggplant } \\
\text { Yield (t/ha) }\end{array}$} & \multirow{2}{*}{$\frac{\text { Ginger }}{\text { Yield (t/ha) }}$} & \multirow{2}{*}{$\frac{\text { Crotalaria }}{\text { Yield (t/ha) }}$} & \multirow[t]{2}{*}{$\operatorname{PAR}\left(\mu \mathrm{mol} / \mathrm{m}^{2} / \mathrm{s}\right)$} \\
\hline & & Grain yield (t/ha) & Biomass (t/ha) & & & & \\
\hline \multirow[t]{3}{*}{ At onset of cropping season A } & $2 \times 2 m$ & $0.00 \mathrm{~d}( \pm 0.00)$ & $0.02 d( \pm 0.00)$ & $1.51 \mathrm{~cd}( \pm 0.49)$ & $1.19 b( \pm 0.21)$ & NA & NA \\
\hline & $4 \times 4 m$ & $0.01 d( \pm 0.00)$ & $0.06 d( \pm 0.00)$ & $2.70 c( \pm 0.57)$ & $1.65 b( \pm 0.26$ & NA & NA \\
\hline & Monocrop & $0.02 d( \pm 0.00)$ & $0.17 d( \pm 0.01)$ & $6.37 a( \pm 1.60)$ & $2.86 \mathrm{a}( \pm 0.40$ & NA & NA \\
\hline \multirow[t]{3}{*}{ At onset of cropping season B } & $2 \times 2 m$ & NA & NA & $1.33 d( \pm 0.34)$ & $1.02 b( \pm 0.69)$ & $2.9 \mathrm{a}( \pm 0.3)$ & $742 c$ \\
\hline & $4 \times 4 m$ & NA & NA & $2.29 \mathrm{~cd}( \pm 0.29)$ & $1.13 b( \pm 0.70)$ & $4.1 \mathrm{a}( \pm 1.0)$ & $1322 b$ \\
\hline & Monocrop & NA & NA & 4.30b $( \pm 0.59)$ & $1.46 \mathrm{~b}( \pm 0.83)$ & $5.1 \mathrm{a}( \pm 1.0)$ & $1817 a$ \\
\hline \multirow[t]{3}{*}{ Dry season } & $2 \times 2 m$ & $0.03 c( \pm 0.00)$ & $0.11 \mathrm{c}( \pm 0.01)$ & NA & NA & NA & $603 c( \pm 10)$ \\
\hline & $4 \times 4 m$ & $0.11 b( \pm 0.05)$ & $0.70 b( \pm 0.31)$ & NA & NA & NA & $1485 \mathrm{a}( \pm 12)$ \\
\hline & Monocrop & $0.27 \mathrm{a}( \pm 0.03)$ & $1.65 a( \pm 0.01)$ & NA & NA & NA & $1767 a( \pm 40)$ \\
\hline LSD & & 0.03 & 0.50 & 1.31 & 0.88 & 2.2 & 535 \\
\hline Fpr & & 0.001 & 0.004 & 0.091 & 0.13 & 0.112 & 0.001 \\
\hline
\end{tabular}

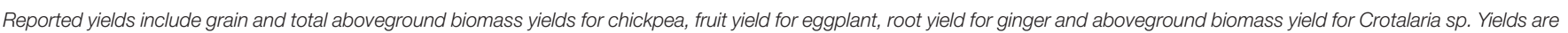

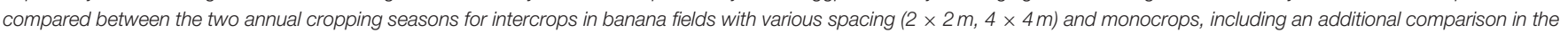

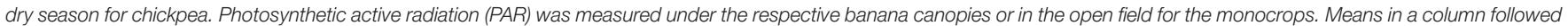
by the same letter are not significantly different from each other according to Tukey's HSD test ( $p<0.05)$. Standard deviations are provided between brackets. NA, not assessed.

dry season (May- August/September) to $865 \pm 469 \mu \mathrm{mol} / \mathrm{m}^{2} / \mathrm{s}$ (Table 4).

At Kavumu, PAR stayed relatively high, with PAR ranging between 587 and $903 \mu \mathrm{mol} / \mathrm{m}^{2} / \mathrm{s}$ under the open spaced $(3 \times$ $4 \mathrm{~m}$ ) and generally less robust-structured beer banana cultivar "Nshika", accounting for a 52-67\% decline in light intensity relative to the light reaching the monocrops (Table 5).

\section{Sensitivity of the Crops to Shade}

An overview of the performance of all crops intercropped in the various banana fields compared to the monocrops is provided in Figure 2. Details on the yields attained in each cropping formation for each crop type can be found across Tables 2-7.

\section{Taro}

Two taro varieties, "Ishikazi" and "Astrida," were, respectively, assessed at the Katana and Kavumu sites. High tuber yields were achieved for both taro varieties in monocrop at either site (40.2 \pm $9.9 \mathrm{t} / \mathrm{ha}$ and $37.9 \pm 20.4 \mathrm{t} / \mathrm{ha}$ at Katana and Kavumu, respectively (Tables 2, 5). At Katana however, significant reductions in tuber yield were recorded for intercropped plants, declining from 7.5 $\pm 1.3 \mathrm{t} /$ ha in the $3 \times 4 \mathrm{~m}$ plot to $1.7 \pm 0.8 \mathrm{t} / \mathrm{ha}$ in the $2 \times 2 \mathrm{~m}$ plot (Table 2). At Katana, total plant height did not significantly differ between the mono-cropped and intercropped taro plants at plant spacings of $2 \times 2,2 \times 3$, and $3 \times 3 \mathrm{~m}$. At Kavumu, tuber yields were high in both cropping seasons with an equally good performance in the intercrop (an average high yield of $44 \pm 8$ t/ha) compared with the monocrop (Table 5).

Taro leaf yields at Katana were higher $(1.4 \pm 0.3 \mathrm{t} / \mathrm{ha})$ in the monocrop compared with yields of $0.2-0.7 \mathrm{t} / \mathrm{ha}$ under the intercropped "Nshika" fields $(2 \times 2,2 \times 3,3 \times 3 \mathrm{~m})$ and $0.3 \pm$ $0.1 \mathrm{t} /$ ha in the $3 \times 4 \mathrm{~m}$ mixed banana cultivar field (Table 2). There was a general reduction in taro tuber yields with increasing leaf pruning for both the mono-cropped and intercrops plants, though no significant differences were observed between the leaf cutting treatments within each planting density. For example, compared to $40.2 \pm 9.9 \mathrm{t} / \mathrm{ha}$ in the treatment with no leaf cutting, yield of tubers was reduced to $30.8 \pm 3.6 \mathrm{t} / \mathrm{ha}$ and $25.2 \pm 6.4 \mathrm{t} / \mathrm{ha}$ when $33 \%$ and $50 \%$ of leaves were harvested, respectively, in the monocrop (Table 2).

\section{Cassava}

Cassava tuber and fresh leaf yield, only assessed at Katana (Table 2), was highest in the monocrop and when no young leaves were harvested, with mean yields of $27.7 \pm 5.0 \mathrm{t} / \mathrm{ha}$ and $9.4 \mathrm{t} / \mathrm{ha}$, respectively. Cassava tuber and leaf yield were significantly lower in the intercrop treatment than in the monocrop, with no significant differences observed between the intercrop treatments. Tuber yield under the $2 \times 2 \mathrm{~m}$ to $3 \times$ $4 \mathrm{~m}$ spaced banana fields varied between 0 and $3.2 \mathrm{t} / \mathrm{ha}$ while yield of fresh cassava leaves varied between 0.05 and $0.35 \mathrm{t} / \mathrm{ha}$. Both cassava tuber and leaf yields decreased significantly in the monocrop when young leaves were harvested during the growing season, with an average retained yield (standing plant) of 8.0-13.1 t/ha and 3.6-5.0 t/ha for tubers and leaves, respectively. Similar trends to that of cassava tuber and leaf yield were observed for cassava plant height (Table 2).

Other cassava plant characteristics (including total stem weight and total root weight (combined weight of edible and non-edible roots; Supplementary Table 3) were also larger in the monocrop. In general, the reduction in the total root and stem weight also increased with increasing planting density.

\section{Yam}

Yams were only assessed at Katana. No significant differences $(p \leq 0.05)$ in yam tuber yields were observed in between the treatments though a higher yield of $9.82 \pm 4.98 \mathrm{t} / \mathrm{ha}$ was attained in the monocrop field (Table 2). In the "Nshika" banana-yam intercrop, yam yields declined with increasing shade intensity, varying between $5.66 \pm 1.36$ t/ha in the $3 \times$ 
TABLE 4 | Mucuna biomass yields across the sites INERA-Mulungu, Kavumu, and Katana for various cropping periods.

\begin{tabular}{|c|c|c|c|c|c|}
\hline Site & Cropping period & $\begin{array}{l}\text { Cycle duration } \\
\text { (months) }\end{array}$ & Banana spacing & Biomass yield (t/ha) & $\operatorname{PAR}\left(\mu \mathrm{mol} / \mathrm{m}^{2} / \mathrm{s}\right)$ \\
\hline \multirow[t]{4}{*}{ Katana } & Cropping season B & 3 & $2 \times 2 m$ & $2.38 \mathrm{ab}( \pm 2.27)$ & $41 b( \pm 22)$ \\
\hline & & & $3 \times 3 m$ & $4.95 \mathrm{a}( \pm 0.31)$ & $170 \mathrm{~b}( \pm 137)$ \\
\hline & Long dry season (May-August) & 4 & $3 \times 4 \mathrm{~m}$ & $0.8 \mathrm{~b}( \pm 0.88)$ & 143b (土135) \\
\hline & & & Fpr & 0.011 & 0.001 \\
\hline \multirow[t]{12}{*}{ INERA-Mulungu } & $\begin{array}{l}\text { Cropping season B, Extended over } \\
\text { dry season }\end{array}$ & 5.5 & $2 \times 2 m$ & $2.76 d( \pm 1.04)$ & 407c ( $( \pm 295)$ \\
\hline & & & $4 \times 4 m$ & $4.53 \mathrm{bc}( \pm 0.00)$ & $720 \mathrm{bc}( \pm 238)$ \\
\hline & & & Monocrop & $5.84 a( \pm 1.61)$ & 1783a $( \pm 20)$ \\
\hline & $\begin{array}{l}\text { Short dry season in between cropping } \\
\text { seasons (December to February) }\end{array}$ & 3 & $2 \times 2 m$ & $2.75 d( \pm 0.35)$ & NA \\
\hline & & & $4 \times 4 m$ & $3.78 c( \pm 0.33)$ & NA \\
\hline & & & Monocrop & $4.89 b( \pm 0.09)$ & NA \\
\hline & & 3 & $3 \times 4 m$ & $1.18 \mathrm{e}( \pm 0.30)$ & 1116b ( $( \pm 299)$ \\
\hline & Long dry season (May to August) & 4 & $2 \times 2 m$ & $0.20 \mathrm{~g}( \pm 0.05)$ & NA \\
\hline & & & $4 \times 4 m$ & $0.73 e g( \pm 0.18)$ & NA \\
\hline & & & Monocrop & $1.10 \mathrm{e}( \pm 0.22)$ & $1828 \mathrm{a}( \pm 189)$ \\
\hline & & 4 & $3 \times 4 m$ & $0.55 c( \pm 0.09)$ & 865b ( $( \pm 469)$ \\
\hline & & & LSD & 0.83 & 338.4 \\
\hline \multirow{7}{*}{ Kavumu } & & & Monocrop & $1.39 c( \pm 0.94)$ & 1898a $( \pm 0)$ \\
\hline & $\begin{array}{l}\text { In between cropping seasons, } \\
\text { extended over cropping season B }\end{array}$ & 6 & $3 \times 4 m$ & $1.09 c( \pm 0.57)$ & $543 b( \pm 197)$ \\
\hline & & & Monocrop & $4.12 b( \pm 0.79)$ & $1756 \mathrm{a}( \pm 0)$ \\
\hline & Long dry season (May- August) & 4 & $3 \times 4 m$ & $0.08 f( \pm 0.06)$ & $639 \mathrm{~b}( \pm 410)$ \\
\hline & & & Monocrop & $1.04 c( \pm 0.79)$ & $1896 a( \pm 34)$ \\
\hline & & & LSD & 0.69 & 568.0 \\
\hline & & & Fpr & 0.001 & 0.924 \\
\hline
\end{tabular}

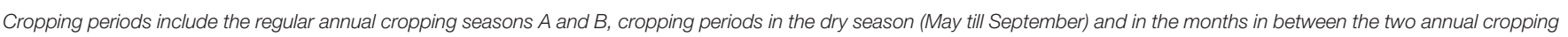

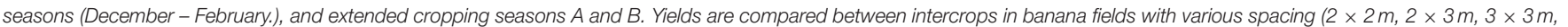

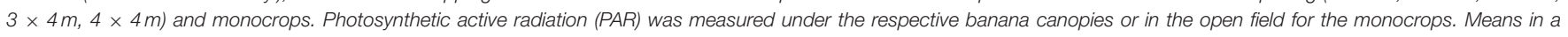

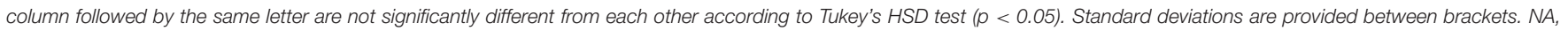
not assessed (Figure $\mathbf{3 A - E}$ ).

$3 \mathrm{~m}$ spaced banana fields to $3.74 \pm 1.39 \mathrm{t} / \mathrm{ha}$ in the denser $2 \times 2 \mathrm{~m}$ banana fields. In the $3 \times 4 \mathrm{~m}$ mixed cultivar field that was heavily shaded, yam tuber yield was also relatively low $(3.45 \pm 3.61)$.

\section{Chili}

Red bird's eye (chili) was only assessed at Katana. Only aboveground biomass yield was assessed for chili (Table 2). A significantly higher $(p \leq 0.001)$ chili biomass yield 
TABLE 5 | Yield and growth attributes of crops grown at Kavumu: tuber crop taro (variety "Astrida"), legume crop soybean and forage grasses Brachiaria sp. and Setaria sp.

\begin{tabular}{|c|c|c|c|c|c|c|c|c|c|}
\hline \multirow[t]{2}{*}{ Planting period } & \multirow{2}{*}{$\begin{array}{l}\text { Banana } \\
\text { spacing }\end{array}$} & \multirow{2}{*}{$\begin{array}{c}\text { Taro } \\
\begin{array}{c}\text { Tuber yield } \\
\text { (t/ha) }\end{array}\end{array}$} & \multicolumn{2}{|c|}{ Soybean } & \multicolumn{2}{|c|}{ Brachiaria sp. } & \multicolumn{2}{|c|}{ Setaria sp. } & \multirow{2}{*}{$\begin{array}{c}\text { PAR } \\
\left(\mu \mathrm{mol} / \mathrm{m}^{2} / \mathrm{s}\right)\end{array}$} \\
\hline & & & $\begin{array}{c}\text { Grain yield } \\
\text { (t/ha) }\end{array}$ & $\begin{array}{c}\text { Biomass } \\
\text { (t/ha) }\end{array}$ & Height (cm) & Yield (t/ha) & Height (cm) & Yield (t/ha) & \\
\hline \multirow[t]{2}{*}{ Cropping season A } & $3 \times 4 m$ & $49.7 \mathrm{a}( \pm 18.2)$ & 1.6ab $( \pm 0.1)$ & $3.2 \mathrm{a}( \pm 0.6)$ & $56 a( \pm 43)$ & $3.6 \mathrm{a}( \pm 6)$ & $46 \mathrm{a}( \pm 38)$ & $5.7 \mathrm{a}( \pm 6.7)$ & $903 b( \pm 267)$ \\
\hline & Monocrop & $41.7 \mathrm{a}( \pm 19.4)$ & $1.9 \mathrm{ab}( \pm 0.5)$ & $4.1 \mathrm{a}( \pm 0.1)$ & 48b $( \pm 41)$ & $3.7 \mathrm{a}( \pm 5.7)$ & $45 a( \pm 38)$ & $6.0 \mathrm{a}( \pm 5.7)$ & $1896 a( \pm 0)$ \\
\hline \multirow[t]{2}{*}{ Cropping season B } & $3 \times 4 m$ & $38.3 a( \pm 16.1)$ & $0.2 \mathrm{c}( \pm 0.17)$ & $4.0 \mathrm{a}$ & NA & NA & NA & NA & 587c ( $( \pm 185)$ \\
\hline & Monocrop & $34.1 \mathrm{a}( \pm 21.3)$ & $1.2 \mathrm{~b}( \pm 0.47)$ & $5.3 a$ & NA & NA & NA & NA & $1756 \mathrm{a}( \pm 0)$ \\
\hline LSD & & 19.4 & 0.7 & 2.3 & 4.7 & 1.7 & 4.28 & 1.85 & 254.3 \\
\hline Fpr & & 0.78 & 0.2 & 0.8 & 0.002 & 0.89 & 0.65 & 0.66 & 0.8 \\
\hline
\end{tabular}

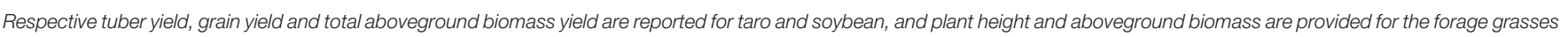

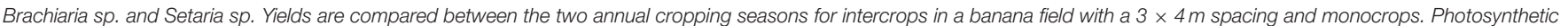

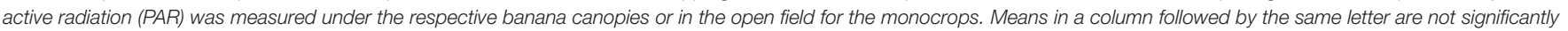
different from each other according to Tukey's HSD test $(p<0.05)$. Standard deviations are provided between brackets. NA, not assessed.

$(5.22 \pm 2.03)$ was observed in the mono-cropped field compared with $0.06 \pm 0.03$ to $0.18 \pm 0.01$ in the intercrops. Biomass yields under banana declined significantly with increasing shade intensity (i.e., reducing PAR) with an average of only $3 \%$ biomass retained across banana plant densities (Table 2).

\section{Crotalaria sp.: Green Manure and Fodder Crop}

Crotalaria sp. was only assessed at INERA-Mulungu. Crotalaria sp. yields increased with increasing PAR values, varying between $2.9 \mathrm{t} / \mathrm{ha}$ in the $2 \times 2 \mathrm{~m}$ plots and $5.1 \mathrm{t} / \mathrm{ha}$ in the monocrop plots. No significant differences were observed between yields in the different shade/PAR levels despite a $20 \%$ and $43 \%$ yield decline in the $4 \times 4 \mathrm{~m}$ and $2 \times 2 \mathrm{~m}$ banana-crotalaria intercrop treatments, respectively, compared to the Crotalaria sp. monocrop (Table 3).

\section{Chickpeas}

Chickpeas were only assessed at the INERA-Mulungu site. Chickpea biomass and grain yield increased with declining shade intensity (Table 3). Significantly higher chickpea biomass and grain yields were attained when planted at the onset of the dry season (May) compared to planting at the onset of the wet season (September). The dry season planting resulted in $0.03 \mathrm{t} / \mathrm{ha}$ (in the $2 \times 2 \mathrm{~m}$ plots) to $0.27 \mathrm{t} / \mathrm{ha}$ in the monocrop compared with yields of $0.00 \pm 0.00$ to $0.02 \pm 0.00$, respectively in the wet season (Table 3).

\section{Eggplant}

Eggplants were assessed at INERA-Mulungu only. Eggplant fruit yield was highest $(6.4 \mathrm{t} / \mathrm{ha})$ in the monocrop and when planted at the onset of cropping season A (Table 3). Eggplant yields declined with declining PAR (i.e., increasing shade level) from $6.4 \mathrm{t} /$ ha in the monocrop to $1.5 \mathrm{t} / \mathrm{ha}$ in the $2 \times 2 \mathrm{~m}$ intercrop in season $\mathrm{A}$ and from $4.3 \mathrm{t} /$ ha in the monocrop to $1.3 \mathrm{t} / \mathrm{ha}$ in the 2 $\times 2 \mathrm{~m}$ intercrop in season $\mathrm{B}$.

\section{Ginger}

Ginger was only assessed at INERA-Mulungu. Ginger had a higher yield for the crop planted under mono-cropped conditions compared to the intercrops, with a higher yield during cropping season A compared to cropping season B (2.9 $\pm 0.4 \mathrm{t} / \mathrm{ha}$ and $1.5 \pm 0.8 \mathrm{t} / \mathrm{ha}$, respectively) (Table 3). Under the intercrops, ginger yield declined with increasing banana plant density, though no significant differences between the $2 \times 2 \mathrm{~m}$ and $4 \times 4 \mathrm{~m}$ banana spacings were observed. No significant differences also occurred between the intercrop and the monocrop in season $\mathrm{B}$.

\section{Mucuna}

The potential of mucuna as a cover plant under varying banana shade intensities and during both the wet season and dry season was assessed by planting it at the onset of a wet or dry season, and in separate trials allowing plants established in the wet season to continue growing during the subsequent dry season months (Figures 3A-E).

At Katana, the wet season mucuna yields increased with increasing PAR or plant spacing, varying between $2.4 \mathrm{t} /$ ha in the 2 $\times 2 \mathrm{~m}$ "Nshika" banana spacing and $5.0 \mathrm{t} /$ ha in the $3 \times 3 \mathrm{~m}$ spaced banana plots. The dry season crop was only assessed under the 3 $\times 4 \mathrm{~m}$ spacing and under monocrop, with higher yields observed under monocropping.

At Kavumu, mucuna yields varied between 0.1 and $6.5 \mathrm{t} / \mathrm{ha}$. The highest mucuna yields were observed in the monocrop established at the beginning of growing season B with extended growth during the subsequent dry season $(6.5 \pm 2.9 \mathrm{t} / \mathrm{ha})$. High yields were also attained in monocrops in the extended season $\mathrm{A}$ and in monocrops planted in between the two growing seasons (early December) and extended toward the end of growing season $\mathrm{B}$ (end of May) $(4.1 \pm 0.8 \mathrm{t} / \mathrm{ha})$. Mucuna yields were consistently higher in the monocrop treatments compared with the $3 \times$ $4 \mathrm{~m}$ intercrop, though the yield of the monocrop planted in September 2015 (cropping season A), and harvested 12 months later, was unexpectedly low $(1.4 \pm 0.1 \mathrm{t} / \mathrm{ha})$ compared to shorter crop cycles (Table 4). This was attributed to the fact that the harvest was delayed and all plants had already shed most of their leaves at time of harvest. Mucuna crop grown solely during the dry season (May-August) had low yields in both the monocrop 


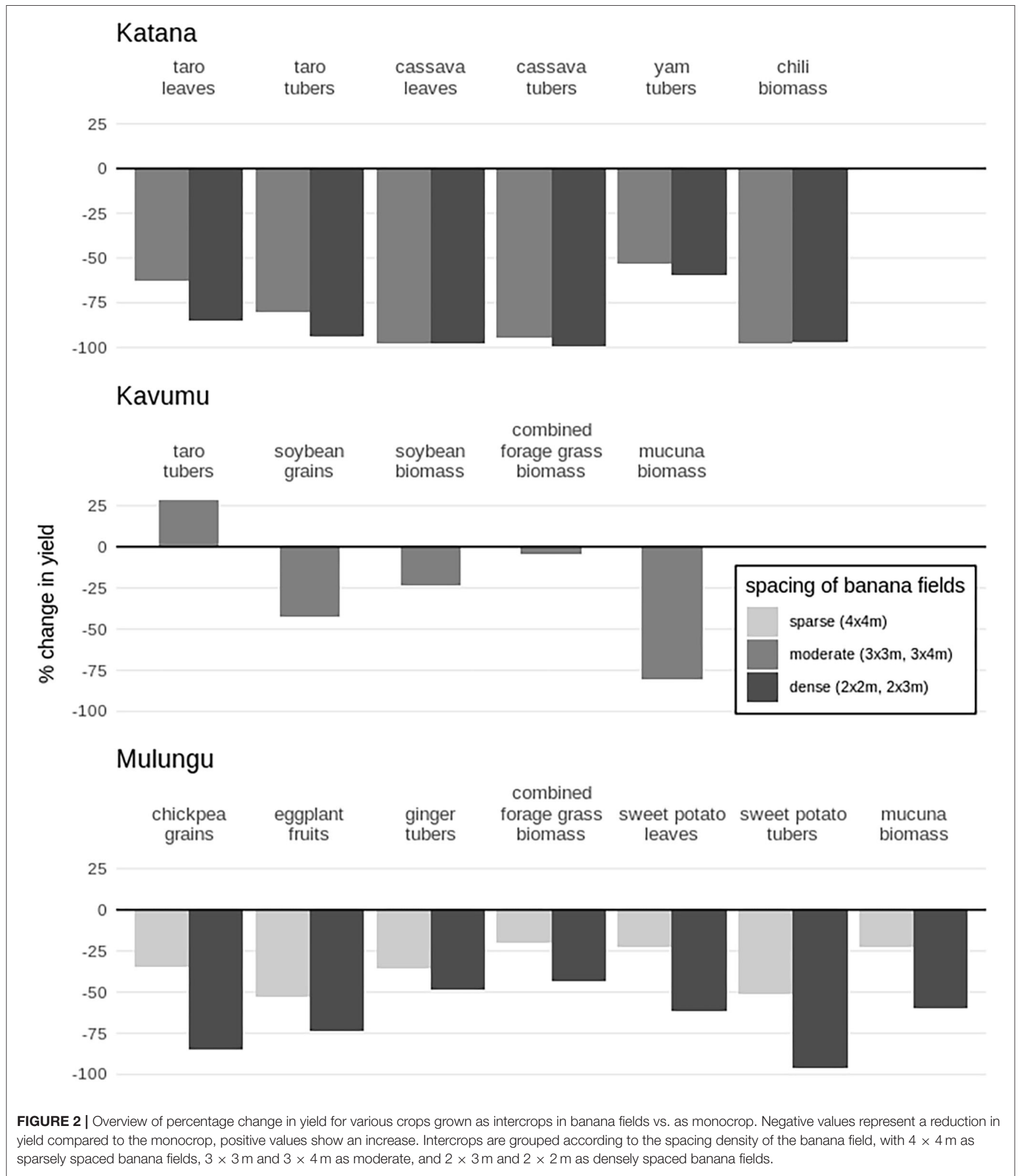

(mean of $0.7 \pm 0.5 \mathrm{t} / \mathrm{ha}$ ) and the $3 \times 4 \mathrm{~m}$ banana intercropped (mean of $0.08 \pm 0.01 \mathrm{t} / \mathrm{ha}$ ) fields.

At INERA-Mulungu, mucuna yields were also higher in the monocrop fields, with yields declining with decreasing PAR values (Table 4). A high mucuna yield of $5.8 \pm 1.6 \mathrm{t} /$ ha was obtained for mucuna monocrop fields (cf. Figure 3A) in the cropping season B (March-May) that was extended toward the end of the subsequent dry season (end of August) to 
provide soil cover. Similarly, high yields of $4.9 \pm 0.1$ and $5.0 \pm 1.1 \mathrm{t} /$ ha were attained for monocrops grown between the two cropping seasons (December-February) and during cropping season A (September-December) extended to February to provide soil cover in between the two cropping seasons, respectively (Table 4$)$. Relatively high mucuna yields $(3.8 \pm 0.3-$ $4.5 \pm 0.0 \mathrm{t} / \mathrm{ha}$; cf. Figure $3 \mathrm{~B}$ ) were also realized in the sparsely spaced banana fields $(4 \times 4 \mathrm{~m})$ cropped between December and February, during the extended season $\mathrm{A}$, and during the extended season B. Mucuna solely grown during the dry season (MayAugust) similar to other sites performed poorly with a yield of $1.1 \pm 0.2 \mathrm{t} / \mathrm{ha}$ in monocrop. Mucuna yields were significantly decreased under the dense $2 \times 2 \mathrm{~m}$ banana fields, varying between $0.2 \pm 0.1 \mathrm{t} /$ ha in the long dry season (May-August) and $2.8 \pm 1.0 \mathrm{t} / \mathrm{ha}$ in season B extended over the long dry season.

\section{Soybean}

Soybean were only evaluated at Kavumu. Soybean were more vegetative, resulting in a higher biomass yield in season B compared to season A. In contrast, higher soybean grain yields were observed in the cropping season A (Table 5). Grain yields of the intercrop were only significantly lower than the monocropped fields during cropping season B, while no significant reduction occurred during cropping season A. Biomass yields were similar in intercrop $(3 \times 4 \mathrm{~m}$ spacing $)$ and monocrop during both cropping seasons.

\section{Forage Grasses}

The forage grasses Brachiaria sp. and Setaria sp. were only assessed at Kavumu. Higher but non-significantly different yield $(p>0.05)$ was observed for the biomass yield of the forages under monocrops than in the intercrop (Table 5). Brachiaria sp. biomass yields varied between 3.6 and $3.7 \mathrm{t} / \mathrm{ha}$ while for Setaria sp. biomass varied between 5.7 and 6.0 t/ha. Despite the non-significant differences in biomass yield of the forages in the intercrop and monocrop, shade was observed to result in significantly taller plants $(p \leq 0.05)$ for Brachiaria $\mathrm{sp}$.

\section{Sweet Potato}

The aboveground (edible) biomass and tuber yields of multiple varieties of sweet potato was assessed at INERA-Mulungu (Table 6). For both the aboveground biomass and tuber yield, the highest yields across all varieties were observed in the monocropped field. "Mugande" and "Elendgi" with aboveground biomass yield varying from 4.5 to $5.8 \mathrm{t} / \mathrm{ha}$ and tuber yield of 14.4 to $15.8 \mathrm{t} /$ ha in the monocrop, performed better than "M'Nzama" and "Vander Wall" with aboveground biomass of 3.0 to 3.2 t/ha and tuber yields of 6.9 to $7.5 \mathrm{t} / \mathrm{ha}$. Similar trends in the performance of the sweet potato varieties was observed in the shade treatments as for the monocrop. For a given sweet potato variety, aboveground biomass and tuber yield declined with a declining level of PAR. Apart from aboveground biomass yields of "Mugande" and "Elendgi" that did not significantly differ under the monocrop and the $4 \times 4 \mathrm{~m}$ treatment, significant differences were visible between the three treatments for both aboveground biomass and tuber yield.
TABLE 6 | Aboveground biomass yield for various sweet potato varieties at INERA-Mulungu.

\begin{tabular}{|c|c|c|c|}
\hline Treatment & $\begin{array}{l}\text { Sweet potato } \\
\text { varieties }\end{array}$ & Biomass (t/ha) & Tuber yield ( $t / h a)$ \\
\hline \multirow[t]{4}{*}{$2 \times 2 \mathrm{~m}$ banana spacing } & Mugande & 1.7def $( \pm 0.3)$ & $0.3 c( \pm 0.2)$ \\
\hline & Elendgi & 1.7 def $( \pm 0.3)$ & $1.0 \mathrm{c}( \pm 0.7)$ \\
\hline & M'Nzama & 1.3ef $( \pm 0.3)$ & $0.2 c( \pm 0.2)$ \\
\hline & Vander wall & $1.0 f( \pm 0.0)$ & $0.3 c( \pm 0.2)$ \\
\hline \multirow[t]{4}{*}{$4 \times 4 \mathrm{~m}$ banana spacing } & Mugande & 4.0abc $( \pm 1.0)$ & $6.1 \mathrm{~b}( \pm 2.6)$ \\
\hline & Elendgi & $4.8 \mathrm{ab}( \pm 0.8)$ & $7.8 \mathrm{~b}( \pm 4.3)$ \\
\hline & M'Nzama & $2.5 \mathrm{cdef}( \pm 0.5)$ & $4.7 \mathrm{bc}( \pm 3.2)$ \\
\hline & Vander wall & $2.3 \mathrm{cdef}( \pm 0.6)$ & $3.3 \mathrm{bc}( \pm 0.8)$ \\
\hline \multirow[t]{4}{*}{ Sweet potato monocrop } & Mugande & $5.8 \mathrm{a}( \pm 2.3)$ & $14.4 \mathrm{a}( \pm 4.6)$ \\
\hline & Elendgi & 4.5ab $( \pm 1.0)$ & $15.8 \mathrm{a}( \pm 2.2)$ \\
\hline & M'Nzama & $3.2 \mathrm{bcd}( \pm 2.0)$ & $7.5 \mathrm{~b}( \pm 4.4)$ \\
\hline & Vander wall & 3.Obcde $( \pm 1.0)$ & $6.9 b( \pm 3.4)$ \\
\hline LSD & & 1.8 & 4.56 \\
\hline Fpr & & 0.3 & 0.099 \\
\hline
\end{tabular}

Yields are compared between intercrops in banana fields with various spacing $(2 \times 2 m, 4$ $\times 4 \mathrm{~m}$ ) and monocrops. Means in a column followed by the same letter are not significantly different from each other according to Tukey's HSD test $(p<0.05)$. Standard deviations are provided between brackets.

\section{Hedge Species}

Forage grasses and shrubs planted along the borders of the banana plots had a similar performance in INERA-Mulungu and Kavumu (Table 7). The grasses of the Pennisetum species ("Fraishe camerounaise" and Pennisetum purpureum) obtained a higher yield than Setaria sphacelata. Of the two forage shrubs, Calliandra calothyrsus showed higher yields than Leucaena leucocephala. At Katana, lower yields were attained for forage grasses along the borders of the monocrop and the "Nshika" banana fields $(3 \times 3,2 \times 3,2 \times 2 \mathrm{~m})$. This is potentially caused by higher local shading conditions from the dense "Nshika" fields and surrounding banana plots. Forage shrubs were not as severely affected by these high shading conditions, with similar yield attained as in Mulungu and Kavumu. Results at Katana show Leucaena sp. to be performing better under full light whereas Calliandra sp. performed better under shaded conditions.

\section{DISCUSSION}

Access to land is a major production constraint in the banana producing landscapes of the East and Central African region. Strategies are as such needed for the optimal use of the available land, especially niches/spaces under the perennial banana crop. Potential options to enable banana intercropping with other annual crops include (i) pruning banana leaves to allow for more light to the shorter stature crops, (ii) use of a wider spacing to minimize shading of the shorter crops, and (iii) integrating moderate to high shade-tolerant intercrops under the banana crop. The option of banana leaf pruning has been shown to be detrimental to the banana crop yield and to perpetuate the spread of the Xanthomonas wilt disease of banana through garden tool use (Ocimati et al., 2019). The efficacy of leaf pruning 
TABLE 7 | Biomass yields of forage grasses and shrubs included as border species across the sites INERA-Mulungu, Kavumu, and Katana center.

\begin{tabular}{|c|c|c|c|c|c|}
\hline Site & & Forage grasses & Yield (kg/2m) & Forage shrubs & Yield $(\mathrm{kg} / 2 \mathrm{~m})$ \\
\hline \multicolumn{6}{|l|}{ Katana } \\
\hline & \multirow[t]{3}{*}{ Monocrop } & Fraishe camerounaise & 4.3abc ( \pm 6.3$)$ & Calliandra & $2.2 \mathrm{ab}( \pm 1.8)$ \\
\hline & & Pennisetum sp. & $3.0 \mathrm{bc}( \pm 4.8)$ & Leucaena & $1.1 \mathrm{bc}( \pm 0.0)$ \\
\hline & & Setaria sp. & $1.2 \mathrm{c}( \pm 1.1)$ & & \\
\hline & \multirow[t]{3}{*}{ Mixed cultivar field $(3 \times 4 \mathrm{~m})$} & Fraishe camerounaise & $8.9 a b( \pm 17.4)$ & Calliandra & 3.3a $( \pm 2.9)$ \\
\hline & & Pennisetum sp. & $10.4 \mathrm{a}( \pm 26.6)$ & Leucaena & $0.3 c( \pm 0.1)$ \\
\hline & & Setaria sp. & $9.2 \mathrm{ab}( \pm 23.4)$ & & \\
\hline & \multirow[t]{5}{*}{ Nshika fields $(3 \times 3,2 \times 3,3 \times 3 \mathrm{~m})$} & Fraishe camerounaise & $0.6 c( \pm 0.9)$ & Calliandra & $2.8 \mathrm{a}( \pm 2.8)$ \\
\hline & & Pennisetum sp. & $1.8 \mathrm{c}( \pm 2.2)$ & Leucaena & $0.5 \mathrm{a}( \pm 2.8)$ \\
\hline & & Setaria sp. & $0.8 \mathrm{c}( \pm 0.7)$ & & \\
\hline & & LSD & 6.2 & & 1.3 \\
\hline & & Fpr & 0.920 & & 0.098 \\
\hline \multirow[t]{5}{*}{ INERA-Mulungu } & & Fraishe camerounaise & $14.0 \mathrm{a}( \pm 13.8)$ & Calliandra & $2.3 \mathrm{a}( \pm 2.4)$ \\
\hline & & Pennisetum sp. & 13.0a ( \pm 16.3$)$ & Leucaena & $0.5 b( \pm 1.4)$ \\
\hline & & Setaria sp. & $5.3 b( \pm 5.5)$ & & \\
\hline & & LSD & 5.4 & & 1.3 \\
\hline & & Fpr & 0.003 & & 0.01 \\
\hline \multirow[t]{5}{*}{ Kavumu } & & Fraishe camerounaise & $12.2 \mathrm{a}( \pm 10.6)$ & Calliandra & $3.6 \mathrm{a}( \pm 2.2)$ \\
\hline & & Pennisetum sp. & 12.0a ( $( \pm 10.6)$ & Leucaena & $1.2 b( \pm 0.9)$ \\
\hline & & Setaria sp. & $5.3 b( \pm 3.5)$ & & \\
\hline & & LSD & 3.5 & & 1.3 \\
\hline & & Fpr & 0.001 & & 0.001 \\
\hline
\end{tabular}

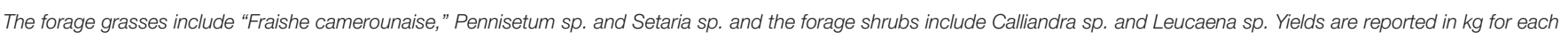

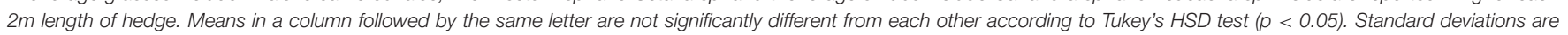
provided between brackets.

will also depend on the level of leaves pruned and the spacing and size of banana mats. The extensive field trials performed in the South Kivu province of eastern DR Congo allowed for the identification of a variety of potentially favorable intercrops for the intensification of banana production systems. Extending production into the dry season months also offers an opportunity to optimally use the available land. Albeit only to a limited extent and for a few crops, this study also gives evidence that additional biomass for food or forage could be attained through the integration of crop spp. that are less sensitive to the long dry weather conditions of the dry seasons.

\section{Sensitivity/Tolerance of Intercrops to Banana Shade}

Although the investigated intercrops attained the highest yields when grown in open fields, a wide range of yield performance was observed under shaded conditions, with no significant differences observed between the intercrops and monocrops in a few cases (overview in Figure 2). Yam, sweet potato, ginger and forage grasses showed good potential for use in the high and moderate banana shade levels, while taro, soybean, mucuna, chili, eggplant, and Crotalaria sp. showed good yield in sparsely spaced banana fields with moderate shading. The cassava variety used in the study was highly sensitive to shade. Investigating variation in yield performance in contrasting cropping seasons revealed a differential performance of the intercrops between the two seasons. Several crops, including soybean, eggplant, and ginger performed better in cropping season A (SeptemberDecember) which is characterized by a high rainfall over a longer rainfall duration.

\section{Inter-cropping With Various Crop Types Under Banana Canopies}

Of all investigated tuber crops, yam showed the best potential for intercropping in both sparsely spaced and dense banana fields. In sparsely spaced fields $(3 \times 3 \mathrm{~m})$, yam achieved equally high yields as in an open field, while in the densest banana fields ( 2 $\times 2 \mathrm{~m}$ and $2 \times 3 \mathrm{~m}$ ) a reasonable reduction in tuber yield of $60 \%$ was attained (cf. Figure 2). At our trials, yam tuber yields were also least affected by shade (with yield reduction of $42-65 \%$ ) compared to the other assessed crops (Figure 2), suggesting that yam could potentially contribute to increasing plot level biomass in banana fields. Reports on yam have mostly shown a moderate shade tolerance, with larger leaves and smaller tubers produced in shaded conditions (Onwueme and Charles, 1994; Johnston and Onwueme, 1998). In the current study only one yam variety was however explored. Studies to evaluate a wider set of yam cultivars for shade-tolerance is hence recommended.

Taro, while attaining high yields in the sparsely spaced banana field at Kavumu $(3 \times 4 \mathrm{~m})$, showed a $88 \%$ drop in tuber yields under denser banana canopies at Katana. This contrasts other studies that have indicated that taro and other aroids show a high level of shade-tolerance related to a greater proportional increased leaf size combined with higher stomatal, chlorophyll 

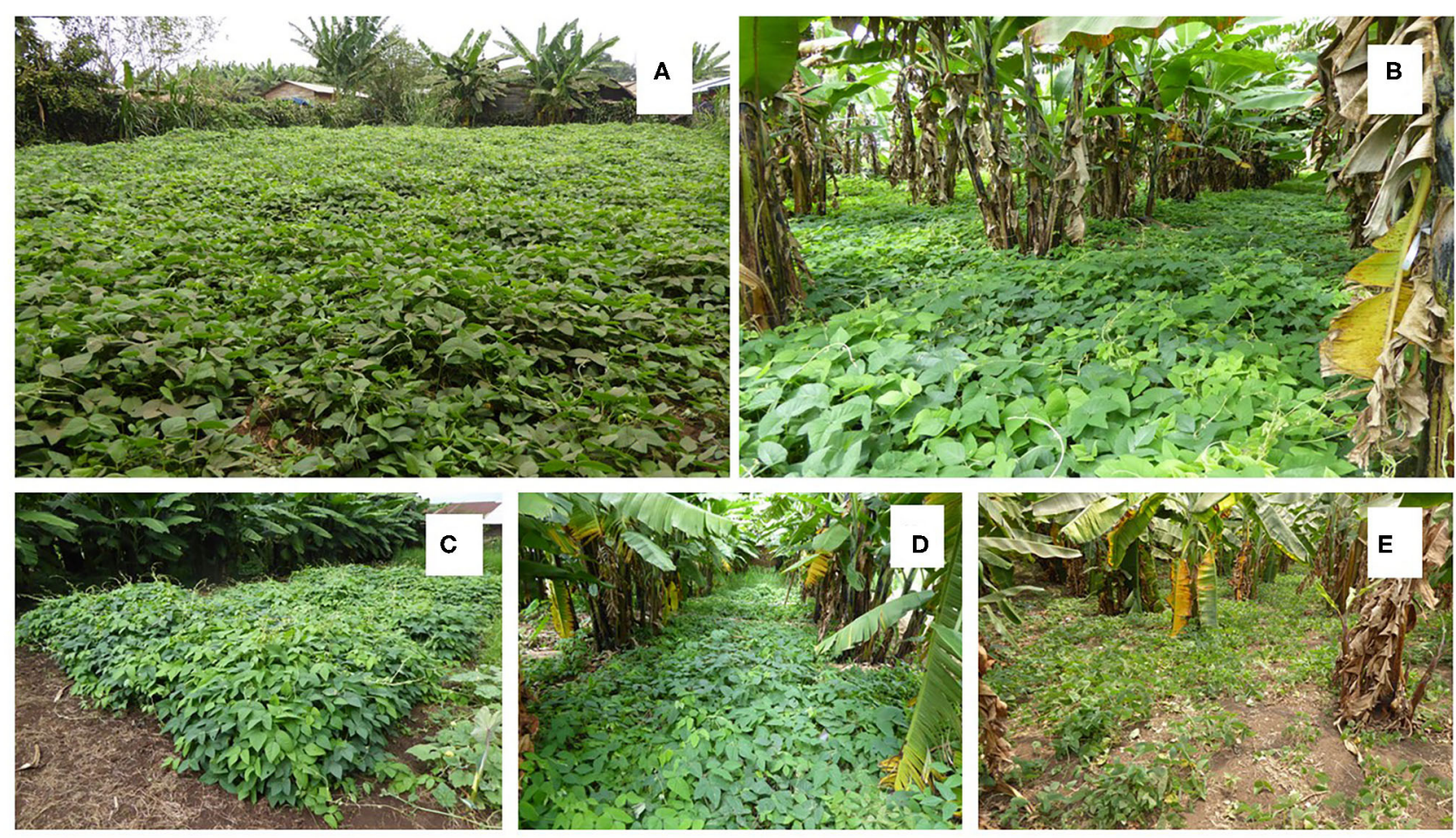

FIGURE 3 | Mucuna grown as a monocrop (A,C) and as an intercrop under $3 \times 4 \mathrm{~m}$ spaced banana fields (B,D,E). Mucuna monocrop (A) was planted in May 2016 (at the end of season B and start of the long dry season) (photo was taken in the dry season, in August 2016) while monocrop (C) was planted in December 2016 at the onset of the short dry season and extended over cropping season B (photo was taken in the rainy season, in April 2017). Mucuna intercrop in (B) was planted in early March 2016 at the onset of the rainy season B (photo taken in the rainy season in April); intercrop in (D) was planted at the start of the short dry season

(December 2016) and extended over cropping season B (photo was taken in the rainy season, in April 2017); and (E) a mucuna intercrop planted at the onset of the long dry season in May 2016 (photo was taken at the end of the long dry season in August 2016). Rainy season B stretches from start of March to end of May, the long dry season from end of May/ start of June to end of August and the short dry season from end of December to end of February. Photos (A,E) were taken at the Katana site, (C,D) at the Kavumu site, while (B) was taken at the INERA-Mulungu site.

and carotenoids density compared to other tuber crops (Rogers and Iosefa, 1993; Johnston and Onwueme, 1998; Onwueme and Johnston, 2000). Rogers and Iosefa (1993) however reported a significant shade by cultivar interaction, and the taro variety "Ishikazi" used at Katana might not be suited for intercropping under the shade of banana fields. The taro variety "Astrida," although only tested in sparsely spaced banana fields, could be of a greater potential. Thus, the need to take stock and evaluate a larger number of taro and other aroids under banana shade.

The tuber crops cassava and sweet potato are reported to have a low tolerance to shade as compared to other tropical tuber crops (Johnston and Onwueme, 1998). Indeed, the tuber yield of cassava was particularly poor under heavily shaded conditions at the trial in Katana, with a yield reduction of $89 \%$ in the most sparsely spaced banana fields (i.e., $3 \times 3 \mathrm{~m}$ and $3 \times 4 \mathrm{~m}$ ), and $100 \%$ tuber yield reduction in the denser plots. Cassava grown in shaded conditions show a large delay in their root bulking process, while the number of roots per plant is reduced (Okoli and Wilson, 1986). Dry matter (DM) allocation plasticity has been shown to lead to more DM allocation to the shoots when carbon dioxide or light is limiting and to the roots when nutrients or water are limiting (Bloom et al., 1985; McCarthy and Enquist, 2007). The production of cassava in shaded conditions is sometimes done specifically to obtain a harvest of edible leaves (Latif and Müller, 2015; Munyahali et al., 2017). Nevertheless, the cassava crop at Katana also showed a significant reduction in leaf yield in both sparsely spaced and dense banana fields, with a limited retained yield of $4 \%$ to $1 \%$ compared to the monocrop. Sweet potato performed better in this respect. Exploring a wider range of cassava varieties, especially for leaf production under banana shade is thus recommended. Tuber yields of the four investigated sweet potato varieties remained relatively high in sparsely spaced banana fields $(4 \times 4 \mathrm{~m})$ with a yield retention of $49 \%$, although retained yield dropped to $4 \%$ in the densest banana fields $(2 \times 2 \mathrm{~m})$. Several varieties of sweet potato showed a good potential for leaf yield in shaded conditions. Although the varieties "Mugande" and "Elendgi" (of which the leaves are used as food and forage) attained higher leaf yields in monocrop than the varieties "M'Nzama" and "Vander Wall' (of which the leaves are consumed as a vegetable), all varieties maintained their leaf yields in the shading of sparsely spaced banana fields and retained $\sim 35 \%$ of yield in the densest fields.

The root crop ginger showed a great potential as an intercrop in banana fields, with a high retained yield even within the densest banana spacing $(2 \times 2 \mathrm{~m})$. Ginger has been reported as a shade-tolerant crop (Okwuowulu, 2005; Lyocks et al., 2013). 
Vanlalhluna et al. (2014) even reported increased rhizome yield from intercropped plots than monocrops, although this is not corroborated with our trial. Ginger additionally produced a higher yield when grown during cropping season $\mathrm{A}$, which is characterized by heavier rainfall. Okwuowulu (2005) reported ginger to be sensitive to the variability in rainfall. Ginger planted during cropping season $\mathrm{B}$ might have been affected by its exposure to long dry conditions in the following dry season, which has been reported to affect rhizome yield (Okwuowulu, 2005). Ginger crop performance might be further optimized through trials with varied planting and harvesting times at the study area. It must also be noted that both ginger and Musa spp. are susceptible to the burrowing nematode (Radopholus similis) (Orton Williams and Siddiqi, 1973; Sipes et al., 2001), and close follow-up of the crops might be advisable.

The eggplant also showed reasonable fruit yields in shaded conditions, with a $46 \%$ yield retained in sparsely spaced banana fields and a further reduction to $27 \%$ in the denser fields. An experimental study indeed showed some degree of shadetolerance of the eggplant with acclimation to low light conditions found for artificially shaded plants (Rosati et al., 2001), although decreased eggplant yields in shaded conditions have also been reported (Uzun, 2007; Pouliot et al., 2012).

The biomass yield of chili under shaded conditions during our trial was surprisingly low, with only $\sim 3 \%$ retained biomass yield across all banana fields $(2 \times 2 \mathrm{~m}$ to $3 \times 4 \mathrm{~m})$ in Katana. Inversely, Pouliot et al. (2012) have reported increased chili pepper yields under tree canopies of up to $150 \%$. Shade tolerance in chili is however dependent on the variety used (Sreelathakumary and Rajamony, 2002), with an increase in chlorophyll density under shaded conditions, potentially increasing photosynthetic efficiency, in several but not all genotypes. Improved genotype selection could therefore potentially improve the performance of chili as an intercrop in banana fields. It is also important to note that in the current study the chili fruit yields were not assessed and there is a high chance that the abundant vegetative biomass in the monocrops could have resulted in lower fruit yields. Repeat experiments assessing fruit yields for multiple chili varieties are thus recommended.

Soybean, although often used as an intercrop in Central Africa, is susceptible to reduced light conditions (Ntamwira et al., 2013). In our experimental trial, soybean performed well in sparse shading of the $3 \times 4 \mathrm{~m}$ banana field at Kavumu, although only during cropping season A characterized by a longer rainfall duration. In cropping season $\mathrm{B}$ and for the same intercropping formation, a lower grain yield of about $17 \%$ of monocrop yield was attained. This could possibly be attributed to the shorter rainfall duration. Other legume crops (e.g., bush bean and climbing bean), although also sensitive to reduced light (Blomme et al., 2018), cope better in low levels of shade than soybean (Ntamwira et al., 2013) and might be more suitable for intercropping in sparsely spaced banana fields.

The incorporation of forage grasses, legume mucuna and shrubs, either as an intercrop or as border delineation showed good potential to offer additional biomass on farm. Although grasses were not assessed for heavily shaded conditions, our experimental trials showed high yields in both sparsely spaced banana fields and along the border of the plots. An in-depth survey conducted by Mpiira et al. (2013) however showed that farmers generally don't plan for managed forage shrubs (and in extension grasses) which are rather present as spontaneous vegetation. Management of forage crops would however improve access to forage for livestock, improve nutrient recycling through mulch and manure and control soil erosion, thus benefiting the banana production system.

\section{Crop Sensitivity to the Long Dry Weather During the Dry Seasons}

The mucuna crop showed variable results when grown solely during the dry season. At Katana, relatively high yields were attained during the dry season while this was not the case at INERA-Mulungu. The high soil fertility at Katana could potentially explain this difference. Another option is to establish mucuna during the annual cropping season and extend its growth into the dry season. Results from this study have shown that mucuna is resilient to exposure to drier conditions after the crop has been established, and high yields can be retained. The ability of the crop to produce all year round enables for its differential promotion, targeting different farm types and priorities. For example, smallholder farms predominantly intercrop banana with other short-stature food crops during the rainy seasons, hence, the integration of mucuna as a cover crop with establishment in the rainy season and extension over the dry season could be hampered. Integration of mucuna toward the end of the rainy season (when annual intercrops are getting mature/ready to be harvested) could be promoted for this category of farmers. For medium to large scale farmers who often grow banana as a monocrop, mucuna could be planted in the rainy season, allowing it to establish all year round. This could enable farmers to cut on labor costs for weeding, support soil and water conservation and improve nutrient recycling in the system.

Chickpea showed great potential for intercropping in banana fields during the dry season. Although the grain yield does reduce with increased shading, an 8-fold yield increase was attained for the crop during the dry season relative to the wet season crop in both sparsely spaced and dense banana fields. Chickpea is indeed often grown in drier conditions through establishment on residual moisture from the rainy season (Varshney et al., 2014). While shading constrains chickpea yield production (Saxena and Sheldrake, 1980), implementation during the dry season not only provide yields outside of the usual cropping season but provides important soil cover protecting against soil degradation.

\section{Challenges and Gaps in the Study}

The current study did not establish the effects of the intercrops on the performance of the banana crop, whole field productivity level or system yield advantage calculations are hence not presented. Intercropping banana with legumes has been observed to reduce the performance of the banana crop though nonsignificantly (Ocimati et al., 2019). However, these authors observed an agronomic advantage of intercropping with these legumes but not an economic advantage (due to the higher value 
of the banana crop in the market), concluding that the choice of farmers could be influenced by their production objectives that could include nutrition, profitability and environment sustainability. It is thus recommended to also explore the agronomic and economic advantages associated with these crop species. Banana cultivars used in the study varied from one site or experiment to the other and the levels of shade did not only vary with the banana spacing/ plant densities but also with the banana cultivar type. To overcome this, the effect of level of shade measured as PAR was used as a uniform parameter to assess growth and yield of intercrops. Nevertheless, future studies could assess a wide range of Musa cultivars and their leaf structure or orientation, in relation to resulting shade levels. Such a study could pinpoint banana cultivars with e.g., more erect leaves and could lead to Musa cultivar specific recommendations for intercropping or a range of intercropping scenarios for a cultivar. These studies were also conducted at the high-altitude sites of eastern DR Congo, that receive a relatively high amount of rainfall. Replicating similar trials at sites with low rainfall might give different results.

\section{Final Remarks}

Shade in dense banana fields forms an important constraint for the integration of most short-stature crops. However, even though significant reductions in yield have been recorded, several of the investigated crops show a reasonable yield retention under moderate to high shade levels including taro, soybean, mucuna, chili, eggplant, Crotalaria sp., yam, sweet potato for leaves, ginger, and forage grasses and shrubs. Introducing these crops/species in denser banana fields can be highly beneficial for small-scale farmers, since additional yield is produced without the use of additional farming land and without excessive field management needs. Reduced soil degradation through intercropping with these crops is an important co-benefit of this farming system, although additional research is needed to quantify which crops perform best in this regard. Chickpea and mucuna showed great potential for extending farming production to the dry season, although both crops would probably benefit from establishment at the end of the rainy season, so that a well-established root system can develop before the rains stop. All in all, year-round biomass production and ground cover highly contribute to whole field productivity, and the overall health of the system.

\section{REFERENCES}

Berger, J. D., Turner, N. C., Siddique, K. H. M., Knights, E. J., Brinsmead, R. B., Mock, I., et al. (2004). Genotype by environment studies across Australia reveal the importance of phenology for chickpea (Cicerarietinum L.) improvement. Aust. J. Agric. Res. 55, 1071-1084. doi: 10.1071/AR 04104

Blomme, G., Ocimati, W., Groot, J. C. J., Ntamwira, J., Bahati, L., Kantungeko, D., et al. (2018). "Agroecological integration of shade- and drought tolerant food/forage crops for year-round productivity in banana-based systems under rain-fed conditions in Central Africa," in Proceeding X International Symp. on Banana: ISHS-ProMusa Symp. on Agroecological Approaches to Promote Innovative Banana Production Systems, eds I. Van den Bergh, J-M Risède, and V. Johnson (Montpellier: Acta Hortic), 1196, 41-54. doi: 10.17660/ActaHortic.2018.1196.5

\section{DATA AVAILABILITY STATEMENT}

The raw data supporting the conclusions of this article will be made available by the authors, without undue reservation.

\section{AUTHOR CONTRIBUTIONS}

GB and WO conceived and developed the research concept, contributed to data analysis, and contributed to writing and editing the manuscript. JN contributed to the development of the research concept, conducted the field experiments, collected and analyzed the data, and contributed to manuscript writing. LB, DA, and NS contributed to shaping the research concept, supported the establishment of experiments, data collection, and data interpretation. EK supported data analysis and interpretation, and the writing and editing of the manuscript. All authors contributed to the article and approved the submitted version.

\section{FUNDING}

This study was supported by funds from the Directorate General for Development, Belgium through the Consortium for Improving Agriculture-based Livelihoods in Central Africa (CIALCA), and from the CGIAR Research Program on Roots, Tubers and Bananas, and the CGIAR Fund Donors.

\section{ACKNOWLEDGMENTS}

We would like to thank the Directorate General for Development, Belgium for funding this research through the Consortium for Improving Agriculture-based Livelihoods in Central Africa (CIALCA). We would also like to acknowledge the financial contribution of the CGIAR Research Program on Roots, Tubers and Bananas and the CGIAR Fund Donors.

\section{SUPPLEMENTARY MATERIAL}

The Supplementary Material for this article can be found online at: https://www.frontiersin.org/articles/10.3389/fsufs. 2020.545926/full\#supplementary-material

Bloom, A. J., Chapin, I. I. I. F. S., and Mooney, H. A. (1985). Resource limitation in plants - an economic analogy. Annu. Rev. Ecol. Evol. S. 16, 363-392. doi: 10.1146/annurev.es.16.110185.002051

Chiu, S. B. (2004). Mucuna bracteata dry matter conversion and decay rate of litter. Planter 80, 461-464.

Gebru, H. (2015). A review on the comparative advantage of intercropping systems. J. Biol. Agricul. Healthcare 5, 28-38. Available online at: http:// citeseerx.ist.psu.edu/viewdoc/download?doi=10.1.1.989.4138\&rep=rep1\& type $=$ pdf $($ accessed October 28, 2020).

Jensen, E. S., Hauggaard-Nielsen, H., Kinane, J., Andersen, M. K., and Jørnsgaard, B. (2005). "Intercropping - The practical application of diversity, competition and facilitation in arable organic cropping systems," in Researching Sustainable Systems 2005. Proceedings of the First Scientific Conference of the International Society of Organic Agricultural Research (ISOFAR), U. Köpke, U. Niggli, D. Neuhoff, W. Lockeretz, H. Willer (Bonn), 22-25. 
Johansen, C., Krishnamurthy, L., Saxena, N. P., and Sethi, S. C. (1994). Genotypic variation in moisture response of chickpea grown under line-source sprinklers in a semi-arid tropical environment. Field Crops Res. 37, 103-112. doi: 10.1016/0378-4290(94)90038-8

Johnston, M., and Onwueme, I. C. (1998). Effect of shade on photosynthetic pigments in the tropical root crops: yam, taro, tannia, cassava and sweet potato. Exp. Agric. 34, 301-312. doi: 10.1017/S0014479798343033

Kempers, A. J., and Zweers, A. (1986). Ammonium determination in soil extracts by the salicylate method. Commun Soil Sci Plant Anal. 17, 715-723. doi: 10.1080/00103628609367745

Latif, S., and Müller, J. (2015). Potential of cassava leaves in human nutrition: A review. Trends Food Sci. Tech. 44, 147-158. doi: 10.1016/j.tifs.2015.04.006

Lithourgidis, A. S., Dordas, C. A., Damalas, C. A., and Vlachostergios, D. N. (2011). Annual intercrops: an alternative pathway for sustainable agriculture. Aust. J. Crop Sci. 5, 396-410.

Lunze, L. (1988). Effects of the Traditional Cropping System on Soil Fertility in South Kivu. Soil Fertility Research for Bean Cropping Systems in Africa. Addis Ababa, Ethiopia, 5-9 Sept. 1988. CIAT, African Workshop series.

Lunze, L. (2000). Lunze L. (2000). "Possibilités de gestion de la fertilité des sols au Sud-Kivu montagneux," in Cahiers du Centre D'études et de Recherche Pour la Promotion Rural et la Paix (CERPRU), Vol. 14, 23-26.

Lyocks, S. W. J., Tanimu, J., and Dauji, L. Z. (2013). Growth and yield parameters of ginger as influenced by varying populations of maize intercrop. J. Agric. Crop Res. 1, 24-29. Available online at: http://sciencewebpublishing.net/jacr/archive/ 2013/August/pdf/Lyocks\%20et\%20al.pdf (accessed October 28, 2020).

McCarthy, M. C., and Enquist, B. J. (2007). Consistency between an allometric approach and optimal partitioning theory in global patterns of plant biomass allocation. Funct. Ecol. 21, 713-720. doi: 10.1111/j.1365-2435.2007.01276.x

Mpiira, S., Staver, C., Kagezi, G. H., Wesagi, J., Nakyeyune, C., Ssebulime, G., et al. (2013). "The use of trees and shrubs to improve banana productivity and production in Central Uganda: an analysis of the current situation," in Banana Systems in the Humid Highlands of Sub-Saharan Africa: Enhancing Resilience and Productivity. G. Blomme, B. Vanlauwe, and P. van Asten. Wallingford: CAB International, pp. 150-157. doi: 10.1079/9781780642314.0150

Mulumba, J. W., Nankya, R., Adokorach, J., Kiwuka, C., Fadda, C., De Santis, P., et al. (2012). A risk-minimizing argument for traditional crop varietal diversity use to reduce pest and disease damage in agricultural ecosystems of Uganda. Agric. Ecosyst. Environ. 157, 70-86. doi: 10.1016/j.agee.2012.02.012

Munyahali, W., Pypers, P., Swennen, R., Walangululu, J., Vanlauwe, B., and Merckx, R. (2017). Responses of cassava growth and yield to leaf harvesting frequency and NPK fertilizer in South Kivu, Democratic Republic of Congo. Field Crops Res. 214, 194-201. doi: 10.1016/j.fcr.2017.09.018

Niroula, G. S., and Thapa, G. B. (2005). Impacts and causes of land fragmentation, and lessons learned from land consolidation in South Asia. Land Policy 22, 358-372. doi: 10.1016/j.landusepol.2004.10.001

Ntamwira, J., Pypers, P., van Asten, P., Vanlauwe, B., Ruhigwa, B., Lepoint, P., et al. (2013). "Effect of leaf pruning of banana on legume yield in banana-legume intercropping systems in eastern Democratic Republic of Congo," in Banana Systems in the Humid Highlands of Sub-Saharan Africa: Enhancing Resilience and Productivity, eds G. Blomme, P. van Austen, and B. Vanlauwe (Egham: CAB International), 158-165. doi: 10.1079/9781780642314.0158

Ntamwira, J., Pypers, P., van Asten, P., Vanlauwe, B., Ruhigwa, B., Lepoint, P., et al. (2014). Effect of banana leaf pruning on banana and legume yield under intercropping in farmers' fields in eastern Democratic Republic of Congo. J. Hortic. For. 6, 72-80. doi: 10.5897/JHF2014.0360

Ocimati, W., Karamura, D., Rutikanga, A., Sivirihauma, C., Ndungo, V., Ntamwira, J., et al. (2013). "Agronomic practices for Musa across different agro-ecological zones in Burundi, Eastern Democratic Republic of Congo and Rwanda," in Banana Systems in the Humid Highlands of SubSaharan Africa: Enhancing Resilience and Productivity, eds G. Blomme, B. Vanlauwe, and P. van Asten (Wallingford: CAB International), pp.175-190. doi: 10.1079/9781780642314.0175

Ocimati, W., Ntamwira, J., Groot, J. C. J., Taulya, G., Tittonell, P., Dhed'a, B., et al. (2019). Banana leaf pruning to facilitate annual legume intercropping as an intensification strategy in the East African highlands. Eur. J. Agric. 110, 125923. doi: 10.1016/j.eja.2019.125923

Ocimati, W., Were, E., Groot, J. C., Tittonell, P., Nakato, G. V., and Blomme, G. (2018). Risks posed by intercrops and weeds as alternative hosts to
Xanthomonas campestrispv. musacearum in banana fields Front. Plant Sci 9, 1471. doi: 10.3389/fpls.2018.01471

Okoli, P. S. O., and Wilson, G. F. (1986). Response of cassava (Manihot esculenta Crantz) to shade under field conditions. Field Crops Res. 14, 349-359. doi: 10.1016/0378-4290(86)9 0069-9

Okwuowulu, P. A. (2005). "Ginger in Africa and the Pacific Ocean Islands," in Ginger, The Genus Zingiber, eds P. N. Ravindran, and K. Nirmal Babu (London: Taylor and Francis), 279-303.

Onwueme, I. C., and Charles, W. B. (1994). Tropical Root and Tuber Crops. Rome: FAO, 228.

Onwueme, I. C., and Johnston, M. (2000). Influence of shade on stomatal density, leaf size and other characteristics in the major tropical root crops, tannia, sweet potato, yam, cassava and taro. Exp. Agric. 36, 509-516. doi: 10.1017/S001447970000 1071

Orton Williams, K. J., and Siddiqi, M. R. (1973). Radopholus similis C.I.H. Description of Plant-Parasitic Nematodes, Set 2, No. 27. St. Albans, Herts, UK: Commonwealth Institute of Helminthology, 4.

Ouma, G. (2009). Intercropping and its application to banana production in East Africa: a review. J. Plant Breed. Crop Sci. 1, 13-15.

Pouliot, M., Bayala, J., and Raebild, A. (2012). Testing the shade tolerance of selected crops under Parkiabiglobosa (Jacq.) Benth. in an agroforestry parkland in Burkina Faso, West Africa. Agrofor. Syst. 85, 477-488. doi: 10.1007/s10457-011-9 411-6

Rogers, S., and Iosefa, T. (1993). "Potentials for shade management in agroforestry systems for taro cropping," in Paper presented at: Sustainable Taro Culture for the Pacific Conference (Honolulu, Hawaii, Honolulu (HI): University of Hawaii).

Rosati, A., Badeck, F. W., and Dejong, T. M. (2001). Estimating canopy light interception and absorption using leaf mass per unit leaf area in Solanum melongena. Ann. Bot. 88, 101-109. doi: 10.1006/anbo.2001. 1433

Saxena, N. P., and Sheldrake, A. R. (1980). "Physiology of growth, development and yield of chickpeas in India," in Proceedings of the International Workshop on Chickpea Improvement, 28 February-2 March 1979, Hyderabad, India. Patancheru: ICRISAT, 89-96.

Sipes, B. S., Schmitt, D. P., and Nelson, S. C. (2001). Burrowing nematode, a major pest in the tropics. Plant Dis. 21:3. Available online at: https://www.ctahr. hawaii.edu/oc/freepubs/pdf/PD-21.pdf (accessed October 28, 2020).

Sreelathakumary, I., and Rajamony, L. (2002). Variability, heritability and correlation studies in chilli (Capsicum spp.) under shade. Indian J Hortic. 59, 77-83. Available online at: http://www.indianjournals.com/ijor.aspx? target $=$ ijor $:$ ijh \&volume $=59$ \&issue $=1$ \&article $=016$ (accessed October 28, 2020).

The World Bank Group (2016). Population Density (People per sq. km of Land Area). Available online at: http://data.worldbank.org/indicator/EN.POP. DNST ?end=2015\&start $=2015 \&$ view $=$ map $($ accessed April 13, 2017).

Tinzaara, W., Stoian, D., Ocimati, W., Kikulwe, E., Otieno, G., and Blomme, G. (2018). "Challenges and opportunities for smallholders in banana value chains," in Achieving Sustainable Cultivation of Bananas. Volume 1: Cultivation Techniques, eds G. H. J. Kema. and A. Drenth (Cambridge: Burleigh Dodds Science Publishing), 1-26. doi: 10.19103/AS.2017.0 020.10

Tittonell, P., and Giller, K. E. (2013). When yield gaps are poverty traps: the paradigm of ecological intensification in African smallholder agriculture. Field Crops Res. 143, 76-90. doi: 10.1016/j.fcr.2012. 10.007

UBOS (2010). Uganda Census of Agriculture 2008/2009: Crop Area and Production Report, vol. IV. Kampala: Uganda Bureau of Statistics, 2010.

Uzun, S. (2007). Effect of light and temperature on the phenology and maturation of the fruit of eggplant (Solanum melongena) grown in greenhouses. N. Zeal. J. Crop Hort. 35, 51-59. doi: 10.1080/011406707095 10167

van Asten, P. J. A., Gold, C. S., Okech, S. H. O., Gaidashova, S. V., Tushemereirwe, W., and DeWaele, D. (2004). Soil quality problems in East African banana systems and their relation with other yield loss factors. InfoMusa 13, 20-25. Available online at: https://hdl.handle.net/10568/96412 
van Asten, P. J. A., Wairegi, L. W. I., Mukasa, D., and Uringi, N. O. (2011). Agronomic and economic benefits of coffee-banana intercropping in Uganda's smallholder farming systems. Agric. Syst. 104, 326-334. doi: 10.1016/j.agsy.2010.12.004

Vanlalhluna, P. C., Sahoo, U. K., and Singh, S. L. (2014). "Growth and yield of agricultural crops intercropped under three multipurpose trees (MPTs) in Mizoram, northeast India," in Paper Presented at: 3rd World Congress on Agroforestry, Trees for Life - Accelerating the Impact of Agroforestry (Nairobi: World Agroforestry Centre).

Varshney, R. K., Thudi, M., Nayak, S. N., Gaur, P. M., Kashiwagi, J., Krishnamurthy, L., et al. (2014). Genetic dissection of drought tolerance in chickpea (Cicerarietinum L.). Theor. Appl. Genet. 127, 445-462. doi: 10.1007/s00122-013-2230-6

VSN International Ltd (2009). GenStat 12th Edition. Available online at: www.vsni. co.uk
Wairegi, W. I. L., van Asten, J. A. P., Tenywa, M. M., and Bekunda, A. M. (2010) Abiotic constraints override biotic constraints in East African highland banana systems. Field Crops Res. 117, 146-153. doi: 10.1016/j.fcr.2010.02.010

Conflict of Interest: The authors declare that the research was conducted in the absence of any commercial or financial relationships that could be construed as a potential conflict of interest.

Copyright (C) 2020 Blomme, Ntamwira, Kearsley, Bahati, Amini, Safari and Ocimati. This is an open-access article distributed under the terms of the Creative Commons Attribution License (CC BY). The use, distribution or reproduction in other forums is permitted, provided the original author(s) and the copyright owner(s) are credited and that the original publication in this journal is cited, in accordance with accepted academic practice. No use, distribution or reproduction is permitted which does not comply with these terms. 